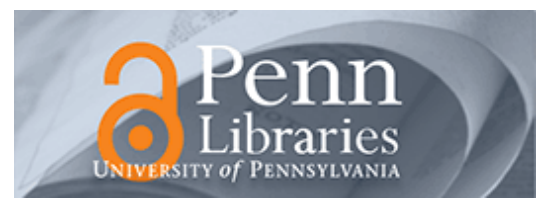

Manuscript Studies

Volume 2

\title{
Statim Prosequi: An Index as a Product, Instrument, and Medium of the Medieval Franciscan Inquisition in Tuscany
}

Geoffrey W. Clement

St. Francis College, gclement@sfc.edu

Follow this and additional works at: https://repository.upenn.edu/mss_sims

Part of the Christianity Commons, European Languages and Societies Commons, History of Christianity Commons, History of Religion Commons, Medieval History Commons, and the Medieval Studies Commons

\section{Recommended Citation}

Clement, Geoffrey W. (2018) "Statim Prosequi: An Index as a Product, Instrument, and Medium of the Medieval Franciscan Inquisition in Tuscany," Manuscript Studies: Vol. 2 : Iss. 2 , Article 1.

Available at: https://repository.upenn.edu/mss_sims/vol2/iss2/1 


\title{
Statim Prosequi: An Index as a Product, Instrument, and Medium of the Medieval Franciscan Inquisition in Tuscany
}

\author{
Abstract \\ Codex Casanatensis Ms. 1730 is a compendious work containing a wide assortment of texts related to \\ the medieval inquisition. This codex was conceived and executed as an unitary whole, and produced in \\ the early fourteenth century for Franciscan inquisitors in Tuscany. While many texts in Casanatensis 1730 \\ appear in other inquisitors' codices, there are also texts that are unique to Ms. 1730. Among these is an \\ index at the start (fol. 1-37) that not only covers Casanatensis 1730 in its entirety, but also contains \\ features that render it especially utilitarian. \\ Through an exploration of these unique features in the index of Casanatensis 1730, it appears that in the \\ index alone, an inquisitor had at hand an alphabetically-arranged mini-libellus that comprised thirty-seven \\ folios of a work that ultimately contains 297 folios, and that set forth his duties, powers, procedures, \\ possible penalties et al. The index was composed in a form that was not only a summary of authoritative \\ lengthy legal texts in the codex, but one that was easily accessible, consultable, and portable. \\ Casanatensis 1730 was never intended to be read from beginning to end. It was an early inquisitorial legal \\ reference work with encyclopedic contents, but those very same contents were reduced to index entries, \\ which are brief summaries, to which inquisitors could quickly and easily refer. The index of Codex \\ Casanatensis 1730 was the medium by which a complex body of legal texts was reduced to its \\ essentials, and re-arranged into a form that could be accessed quickly and easily by anyone in need of \\ such a handy reference guide; thereby expediting the inqusitorial process and better enabling an \\ inquisitopr to "Statim prosequi...immediately prosecute".
}

\section{Keywords}

Medieval, Franciscan Order, Inquisition, Inquisitor manual, Casanatense ms. 1730, index, inquisition text 
Clement: Statim Prosequi: An Index as a Product, Instrument, and Medium of

\section{MANUSCRIPT STUDIES \\ A Journal of the Schoenberg Institute for Manuscript Studies}

VOLUME 2, NUMBER 2

(Fall 2017)

Manuscript Studies (ISSN 2381-5329) is published semiannually

by the University of Pennsylvania Press

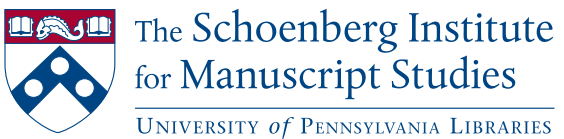




\title{
Manuscript Studies, Vol. 2 [2018], Iss. 2, Art. 1
}

\author{
MANUSCRIPT STUDIES \\ VOL UME 2, N U M B E R 2 \\ (Fall 2017)
}

ISSN 2381-5329

Copyright (C) 2017 University of Pennsylvania Libraries and University of Pennsylvania Press. All rights reserved.

Published by the University of Pennsylvania Press, 3905 Spruce Street, Philadelphia, PA 19104.

Printed in the U.S.A. on acid-free paper.

Manuscript Studies brings together scholarship from around the world and across disciplines related to the study of premodern manuscript books and documents, with a special emphasis on the role of digital technologies in advancing manuscript research. Articles for submission should be prepared according to the Chicago Manual of Style, $16^{\text {th }}$ edition, and follow the style guidelines found at http://mss.pennpress.org.

None of the contents of this journal may be reproduced without prior written consent of the University of Pennsylvania Press. Authorization to photocopy is granted by the University of Pennsylvania Press for libraries or other users registered with Copyright Clearance Center (CCC) Transaction Reporting Service, provided that all required fees are verified with CCC and paid directly to CCC, 222 Rosewood Drive, Danvers, MA 01923. This consent does not extend to other kinds of copying for general distribution, for advertising or promotional purposes, for creating new collective works, for database retrieval, or for resale.

\section{SUBSCRIPTION INFORMATION:}

Single issues: $\$ 30$

Print and online subscriptions: Individuals: \$40; Institutions: \$90; Full-time Students: \$30 International subscribers, please add $\$ 18$ per year for shipping.

Online-only subscriptions: Individuals: \$32; Institutions: \$78

Please direct all subscription orders, inquiries, requests for single issues, address changes, and other business communications to Penn Press Journals, 3905 Spruce Street, Philadelphia, PA 19104. Phone: 215-573-1295. Fax: 215-746-3636. Email: journals@pobox.upenn.edu. Prepayment is required. Orders may be charged to MasterCard, Visa, and American Express credit cards. Checks and money orders should be made payable to "University of Pennsylvania Press" and sent to the address printed directly above.

One-year subscriptions are valid January 1 through December 31. Subscriptions received after October 31 in any year become effective the following January 1 . Subscribers joining midyear receive immediately copies of all issues of Manuscript Studies already in print for that year.

Postmaster: send address changes to Penn Press Journals, 3905 Spruce Street, Philadelphia, PA 19104.

Visit Manuscript Studies on the web at mss.pennpress.org. 


\section{MANUSCRIPT STUDIES}

\section{A Journal of the Schoenberg Institute for Manuscript Studies}

V OL U M 2, N U M B R 2

\section{Articles}

Statim Prosequi: An Index as a Product, Instrument, and Medium of the Medieval Franciscan Inquisition in Tuscany

Geoffrey W. Clement

A Tool for Exemplary Pastoral Care: Three Booklets of the

Edwardes Manuscript in Context

HANNAH WEAVER

Conversational Lollardy: Reading the Margins of

MS Bodley 978

Elizabeth SCHIRMer

"My Written Books of Surgery in the Englishe Tonge":

The London Company of Barber-Surgeons and the Lylye of Medicynes

ERIN CONNELLY

The Two Yohannases of Santo Stefano degli Abissini, Rome: Reconstructing Biography and Cross-Cultural Encounter through Manuscript Evidence

Textual Contents of Pāli Samut Khois: In Connection with the Buddha's Abhidhamma Teaching in Tāvatimusa Heaven Toshiya Unebe

The Western Manuscript Collection of Alfred Chester Beatty (ca. 1915-1930) 
Manuscript Studies, Vol. 2 [2018], Iss. 2, Art. 1

iv | Journal for Manuscript Studies

The St. Chad Gospels: Diachronic Manuscript Registration and Visualization

Stephen Parsons, C. Seth Parker, and W. Brent Seales

\section{Annotations}

An Investigation of the Relationship between Prince Shōtoku's Shōmangyō-gisho and Two Dunhuang Buddhist Manuscripts: A Debate over Originality and Canonical Value Mark Dennis

The Glossa Ordinaria Manuscripts of the Biblioteca Capitolare of Monza

E. Ann MATter

The Summula de Summa Raymundi in Gordan MS 95, Bryn Mawr College

Thomas IzBicki

A Newly Discovered Manuscript of the Historia de los Reyes Moros de Granada by Hernando de Baeza

María Mercedes Delgado Pérez

\section{Reviews}

Albert Derolez. The Making and Meaning of the Liber Floridus: A Study of the Original Manuscript, Ghent, University Library MS 92

MARY FrankLIN-Brown 569

Bent Lerbæk Pedersen. Catalogue of Yao Manuscripts ADAM SMITH

T. L. Andrews and C. Macé, eds. Analysis of Ancient and Medieval Texts and Manuscripts: Digital Approaches 
Clement: Statim Prosequi: An Index as a Product, Instrument, and Medium of

Contents | v

Elizabeth Solopova. Manuscripts of the Wycliffite Bible in the Bodleian and Oxford College Libraries

KathleEn Kennedy

Colour: The Art and Science of Illuminated Manuscripts

Nicholas Herman

List of Manuscripts Cited 


\title{
Statim Prosequi \\ An Index as a Product, Instrument, and Medium of the Medieval Franciscan Inquisition in Tuscany
}

\author{
Geoffrey W. Clement \\ St. Francis College
}

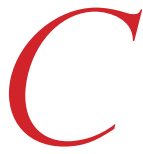

Yodex Casanatensis, MS $1730,{ }^{1}$ was written and compiled in the early fourteenth century for use by Franciscan inquisitors in Florence and Tuscany. Conceived and executed as a unitary whole, and produced largely by a single hand, it is a compendious manuscript that contains a wide typology of legal texts, all pertaining to the medieval inquisition of heresy. As I have argued elsewhere, Casanatensis 1730 is unique since three-quarters of the manuscript was penned by one hand and assembled in a particular order. ${ }^{2}$ While many of the texts in Casanatensis 1730 also appear in other well-known inquisitors' codices, there are a number of texts that are unique to MS $1730 .{ }^{3}$ Among this latter group is an unparalleled

1 Rome, Biblioteca Casanatense MS 1730. Note that I've used the Latin form of the title in this essay, as in the original work; "Casanatense" is the work's modern-day designation.

2 Geoffrey W. Clement, "A Franciscan Inquisitor's Manual and Its Compositional Context: Codex Casanatensis 1730,” Ph.D. diss., Fordham University, 2013.

3 In terms of the historiography of inquisitors' manuals as well as descriptions of contents of numerous Italian and French manuscript collections, see Charles Molinier, "Rapport sur une mission exécutée en Italie (études sur quelques manuscrits des bibliothèques d'Italie concernant l'inquisition et les croyances hérétiques du XIIIe et du XIIIIe siècle)," Archives des missions scientifiques et littéraires, ser. 3, no. 14 (Paris: Imprimerie nationale, 1888): 133-336; Antoine Dondaine, "Le manuel de l'Inquisiteur (1230-1330)," Les bérésies et l'inquisition, 
contemporary index at the start of the book that not only covers Casanatensis 1730 in its entirety, but also contains several features that render it especially utilitarian and practical. ${ }^{4}$ Furthermore, the manuscript incorporated many novelties of the time, including rubricated headlines, Arabic numerals, cross-references, and an extensive alphabetically arranged topical index. Some materials in other hands were later added to produce the codex in its present form, but most of it was conceived and produced in one place, at one time, by one person who was likely an inquisitor himself or a functionary in the service of the inquisition.

For those who may not be familiar with the contents of Casanatensis 1730, the main body of the codex was produced between 1301 and 1314 and largely comprises texts determined by authorship of the original documents and each encompassing two or more gatherings. These include such textual units as the index; two handbooks or formularies; extracts from papal bulls, mostly originating in the second half of the thirteenth century; extracts from the Corpus Iuris Civilis and Gratian's Decretum; collected consilia from councils, such as those at Toulouse and Béziers; and from authoritative prelates of the later thirteenth century. The last document in the original hand was a letter from the papal legate Cardinal Matthew of Aquasparta, former minister-general of the Friars Minor, to the inquisitor in Tuscany, Fra Grimaldo da Prato (fol. 114r). It is dated 1 July 1301-late in the papacy of Boniface VIII (r. 1294-1303). A different hand then added two slightly later documents. The first, Ex eo quod from Benedict XI (r. 1303-1304), was

XIIè-XIIIè siècles (Aldershot, Hampshire: Variorum, 1990), 85-194 [orig. in Archivum Fratrum Praedicatorum 17 (1947): 85-194]. For the contents of Casanatense MS 1730, see Gottfried Opitz, "Über zwei Codices zum inquisitionsprozess; Cod. Cas. 1730 und Cod. des Archivio Generalizio dei Domenicani, II, 63," Quellen und Forscbungen 28 (1937-38): 75-106. 4 Dondaine, "Le manuel de l'Inquisiteur (1230-1330)," 113, classified the index in Casanatense 1730 as a traité raisonné and only remarked that: "la table alphabétique des matières du riche recueil d'origine franciscaine . . . forme un véritable répertoire de l'inquisiteur. Elle n'occupe pas moins de 37 folios d'un recueil où les textes en rapport avec elle en occupent eux-mêmes environ deux cents. C'est un des plus remarquables instruments du genre, et fort pratique, puisqu'il réfère aux seuls textes contenus dans le manuscrit, avec indication des folios et des colonnes.” 
inserted on folio $64 \mathrm{r}-\mathrm{v}$, which was originally left blank by the main writer. ${ }^{5}$ Much later in the manuscript, the same later hand entered a concord regarding an interpretation of the laws of Emperor Frederick II against the heretics between Fra Grimaldo da Prato and Antonio Orso, bishop of Florence. Since the concord is dated 12 August 1314, it provides the terminus post quem this hand made its two additions. Thus, the range of 1301-14 as that during which the majority of the codex proper was produced places it before the appearance of Bernard Gui's famous Practica Inquisitionis, circa 1323, and only a few decades after the dates of the preponderance of papal bulls and constitutions pertaining to the inquisition contained in Casanatensis 1730 .

It is the first thirty-seven folios contained in the first four gatheringsthe index - upon which this paper focuses. ${ }^{6}$ In particular, a few key characteristics of many index entries make Casanatensis 1730 not only especially utilitarian in discharging or expediting an inquisition, but in rendering the manuscript as a medium by which a processus or legal procedure could be more expeditiously moved along. This was accomplished through a simple alphabetical guide that also distilled and summarized inquisitors' powers, procedures, and documentary instruments without necessitating consultation of the authoritative document to which the index directed the user. Furthermore, its organizational principles differ significantly from much shorter and less comprehensive indexes found in other major manuscript collections, especially those currently in Roman archives, relating to the medieval inquisition in central Italy, including Vat. lat. 3978, Vat. lat. 2648, Vat lat. 5092, and Casanatensis MS 969. For these reasons and a pattern of greater frequency of marginalia in the index, the index itself became the

5 Benedict XI, Ex eo quod (2 March 1304), August Potthast, ed., Regesta Pontificum Romanorum, 2 vols. (Berlin: prostat in aedibus Rudolphi Decker, 1874-75), 2:2032, no. 25381; Thomas Ripoll and Antonin Brémond, eds., Bullarium Ordinis Fratrum Praedicatorum, 8 vols. (Rome: Ex Typographia Hieronymi Mainardi, 1729-40), 7:53, no. 39.

6 For an edition and translation of the index to Casanatense 1730, fols. 1-37, see Geoffrey W. Clement, "Franciscan Inquisitors in Tuscany, Early 14th Century: The Index of Codex Casanatensis, ms. 1730,” Fordham Internet History Sourcebook Project, Medieval Sourcebook, http://legacy.fordham.edu/halsall/source/IndextranslationofCasanatense1730.pdf. 


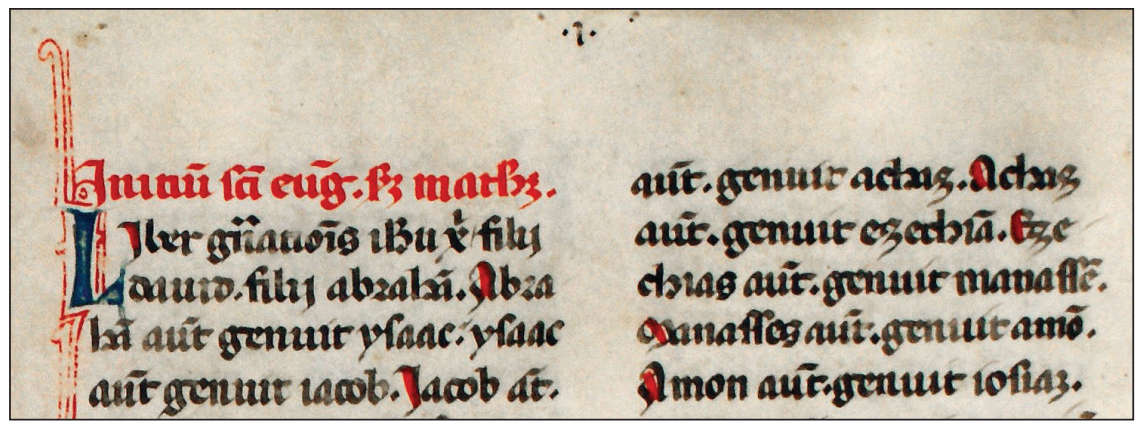

FIGURE 1. Rome, Biblioteca Casanatense MS 1730, fol. 41r.

more commonly used portion of Casanatensis 1730 due to its unique ability to enhance an inquisitor's ability to statim prosequi-immediately prosecute or go after.

Casanatensis 1730 has 297 folios in twenty-seven gatherings. There are two foliation systems in the manuscript - a medieval and a modern one. Both use Arabic numerals and are continuous from their respective points of origin. As figure 1 shows, the medieval foliation begins on modern folio $41 \mathrm{r}$, the first folio of the collection proper after the index. It is contemporary with the composition of the majority of the manuscript both because it is the system used for references in the index, which is unerringly accurate, and the hand of the enumeration in the original index entries, as well as the majority of the entire manuscript, and the medieval foliation is the sameItalian Gothic Bookhand, or Littera Textualis Gotica Italiana. ${ }^{7}$ The first forty folios, comprising gatherings 1-4, thirty-seven of which are the index, are not numbered in the medieval system. The index in Casanatensis 1730 (fols. 1-37) is comprehensive and contemporary to the larger collection that

7 Ricardo Parmeggiani, I Consilia Procedurali per l'inquisizione medievale (1235-1330), (Bologna: Bononia University Press, 2011), XCI; Bernhard Bischoff, Gerard I. Lieftinck, and G. Battelli, Nomenclature des écritures livresques du IXe au XVIe siècle (Paris: Centre National de la Recherche Scientifique, 1954), 16-22; Catalogo dei manoscritti in scrittura Latina datati o databili per indicazione di anno, di luogo o di copistà, Università degli studi di Roma, scuola speciale per archivisti e bibliotecari (Turin: Bottega d'Erasmo, 1971), Farf. 28 (340); see pl. 13 (fol. 33r). 
immediately follows it and uses Latin topical headings that refer the user to a given folio number and column identified by letter.

Some noteworthy aspects of the index include ubiquitous use of Arabic numerals, occasional cross-referencing, and index entries that distill or decontextualize the full-length text of laws and procedures contained in the main body of the codex. All of these features together made Casanatensis 1730 especially useful in its day. The combination of index and texts resulted in a manual that was portable, quickly and easily consulted, and authoritative in its contents, while also allowing for subsequent addenda that updated the codex and were wholly integrated into its index by later hands without changing the wording or order of the index entries themselves. As figures 2, 3, and 4 demonstrate, alphanumerical folio references were added to preexisting index entries by later hands. Indeed, these figures also show that the index was comprehensive and yet flexible enough to accommodate references to later additional texts without necessitating any alteration to its structure because the entries were topical in nature (e.g., abjuration, absolution, accusation, apostasy), and the topical headings were arranged alphabetically. It is the latter two characteristics of Casanatensis 1730's index-cross-referencing and distilled summary index entries — that make it unique.

By assembling a wide range of legal sources and tracts, the initiator of Casanatensis 1730 produced an effective manual for inquisitors, one designed specifically for the Franciscan inquisition in central Italy. Many of the major sections were copied as discrete multi-gathering units, one could say as libelli, except that they were intended for eventual collation, and then arranged in their desired order. The collector then composed an index, which was organized by very different principles from those of the codex proper. In large part, it is the differing organizational principles between the index and the body of the manuscript, coupled with the effective integration of multiple characteristics in the index, that make Casanatensis 1730 a remarkable work.

The utilitarian features of Codex Casanatensis 1730's index were not revolutionary at the time of the codex's composition. There are similar elements described by Mary and Richard Rouse in their work on the development and implementation of finding tools in scholarly reference works from the late twelfth through the thirteenth centuries. These relate directly to 
Clement: Statim Prosequi: An Index as a Product, Instrument, and Medium of 272 | Journal for Manuscript Studies

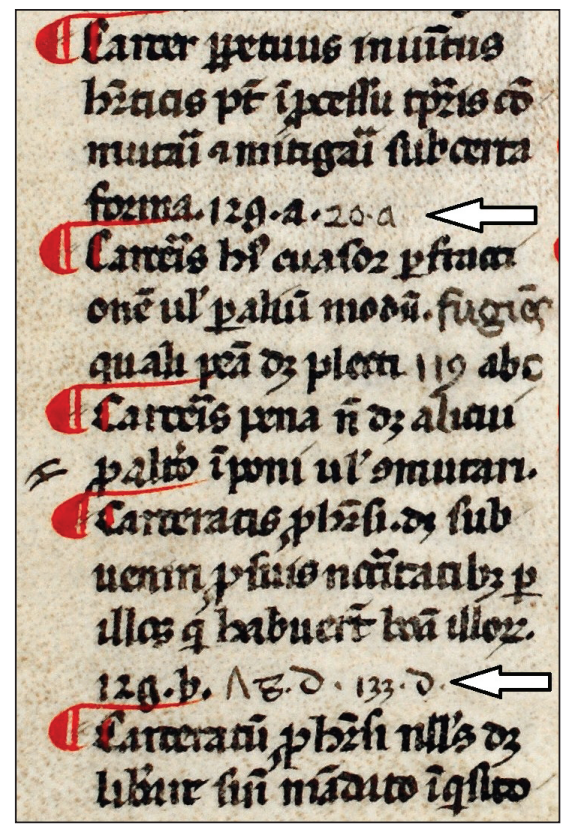

FIGURE 2. Rome, Biblioteca Casanatense MS 1730, fol. 5va, lines 12-27.

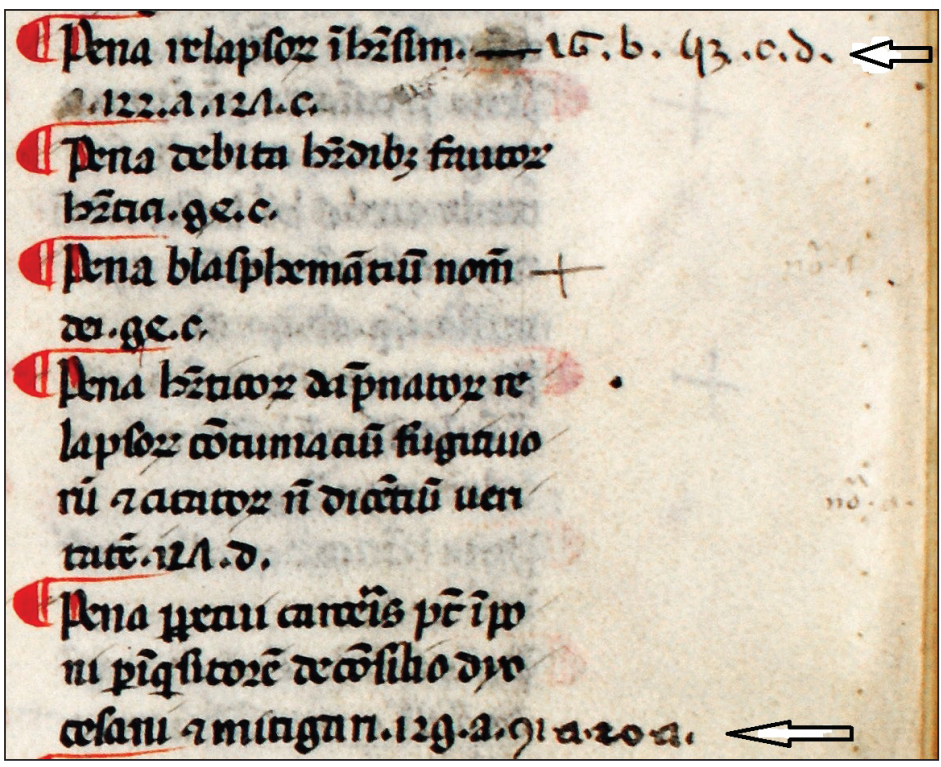

FIGURE 3. Rome, Biblioteca Casanatense MS 1730, fol. 29rb. 
Manuscript Studies, Vol. 2 [2018], Iss. 2, Art. 1

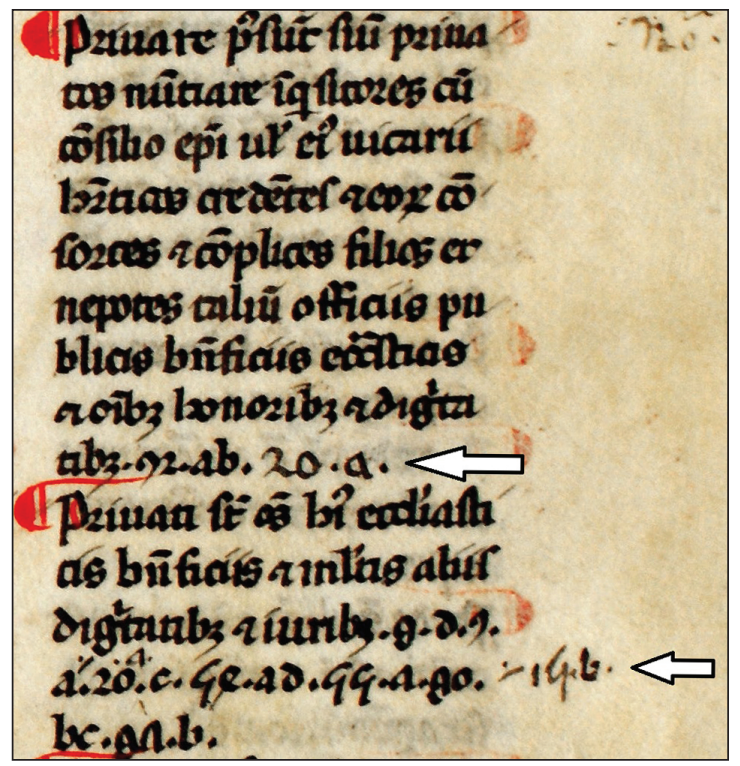

FIGURE 4. Rome, Biblioteca Casanatense MS 1730, fol. $32 \mathrm{rb}$.

many aspects in Casanatensis 1730's index; however, a holistic and comprehensive consideration of the conception, production, and end result that is the codex as an opus completum goes beyond where the Rouses left off. Mary and Richard Rouse approached medieval texts not from the position of what a text says, but why and how it was produced in the first place. ${ }^{8}$ For them, the textual production, not the content of texts, is the protagonist of

8 Mary A. Rouse and Richard H. Rouse, Authentic Witness: Approaches to Medieval Texts and Manuscripts (Notre Dame: University of Notre Dame Press, 1991), esp. chapters 6 and 7, originally published as Richard H. Rouse and Mary A. Rouse, "Statim invenire: Schools, Preachers, and New Attitudes to the Page," Renaissance and Renewal in the Twelfth Century, ed. Robert L. Benson and Giles Constable (Cambridge, MA: Harvard University Press, 1982), 201-25; and Richard H. Rouse and Mary A. Rouse, "La diffusion en Occident au XIIIe siècle des outils de travail facilitant l'accès aux textes autoritatifs," Revue des études islamiques 44 (1976): 114-47. The latter article was later expanded considerably to form part one of Richard H. Rouse and Mary A. Rouse, Preachers, Florilegia and Sermons: Studies on the "Manipulus florum" of Thomas of Ireland, Pontifical Institute of Medieval Studies, Studies and Texts 47 (Toronto: Pontifical Institute of Medieval Studies, 1979), 3-90. 
history and thus can shed light upon the society in which a given textual production, or genre of texts, was produced, as well as the people who produced them and why they did so in a certain format at a given time. ${ }^{9}$ Of particular importance for analyzing the index of Casanatensis 1730 is their work on the early development of finding tools in the latter half of the twelfth century, and the elaboration and utilization of these tools, as well as the invention of some newer research tools in the course of the thirteenth century. The Rouses are primarily concerned with tools devised to assist preachers, university masters, and students, not inquisitorial manuals. But such research tools as the subject index, alphabetization of materials, and Arabic numerals are all present in Casanatensis 1730. This index strongly supports the Rouses' argument and approach, and shows that their work is applicable to a textual genre beyond their original subjects. At the same time, the index of Casanatensis 1730's structural complexity and particular textual characteristics go beyond the devices studied by the Rouses.

Beginning in the twelfth century, and closely linked to the growth of schools and universities, reliance solely upon memory became inadequate as a means for retrieving information. ${ }^{10}$ One need only consider some of the more remarkable works of that century such as Peter Lombard's Sentences, Gratian's Decretum, or the development of the Glossa ordinaria-all landmark works of twelfth-century intellectual changes-to see that memory alone to recall parts, or assemble extracts, from any of these works was a deficient means of approaching such exceptionally voluminous texts. The Rouses remark of these works and others from the period that "one cannot remember what one has not read, and one may well wish to find a part

9 Rouse and Rouse, Authentic Witness, 1; where they pose the essential questions of their inquiry: "Our questions are 'why' and 'how?' Why was it written-from what source? And for what purpose? How was it written (the mechanics, both material and intellectual)? Why at this time? Why by this or these person(s)? Why in this specific form? How and why does it differ from analogues?"

10 Rouse and Rouse, Authentic Witness, 196; see also Michal T. Clanchy, From Memory to Written Record: England 1066-1307, 3rd ed. (Chichester: Wiley-Blackwell, 2013), for an analysis and discussion of the gradual increase in the use and importance of written documents in England and an expanding literate mentality that was its impetus. 
without reading the whole."11 For the Rouses, the insufficiency of memory as a finding device, and hence the need for artificial locating tools, was most notable in Paris, with its growing schools and especially its study of theology. ${ }^{12}$

Unlike prior centuries of the medieval era, where the preponderance of scholarly compositions was produced in a monastic milieu and directed to liturgical ends, the scholarship of the twelfth century becomes progressively characterized by efforts to gather, reconcile, organize, and harmonize the enormous legacy of the Christian past stretching all the way back to the Fathers of the Church. This may have been a matter of educational necessity, according to the Rouses. In the burgeoning cathedral schools and early universities, the needs and limited term of instruction in sacred scripture and centuries of accumulated commentary required artificially devised instruments to assist in a more efficient and effective means of researching these sources. ${ }^{13}$ A change of attitude to the written page was most visible in the later twelfth century through innovations in the layout of a manuscript. These included a group of developments that were intended to assist the master and student in locating a particular item or section within a lengthy work. Running-head lines, rubricated chapter titles, alternating red and blue initials, variations in the size of initial letters, paragraph marks, crossreferences, and citation of authors quoted in the text-all used in Casanatensis 1730 — are among the innovations cited by the Rouses as twelfth-century devices. It is impossible to date precisely when each of these innovations in layout first appeared, except that one is on firm ground in asserting that by 1220 they were all standard techniques used in page layout to assist a reader in locating a desired section or item of information. ${ }^{14}$ Beyond these changes in layout, the compilation of alphabetical subject indexes, though not entirely

11 Rouse and Rouse, “Statim invenire," 206.

12 Rouse and Rouse, "Statim invenire," 205.

13 Rouse and Rouse, "Statim invenire," 202, where they write that their study addresses "the evolution of scholarly apparatus in the second half of the twelfth century: the forms that such instruments took, and the causes of their creation. The explanation of both forms and causes has much to do with the twelfth-century growth of the schools and the needs of formalized instruction."

14 Rouse and Rouse, "Statim invenire," 207. 
heretofore unknown, grew in importance, and the range of sources for which they were compiled also expanded. Indeed, it was not until the third quarter of the thirteenth century that a subject index for Gratian's Decretum was produced. ${ }^{15}$

A subject index required alphabetization if it was to be used for a wide range of issues. This constitutes a shift in organizational schema when the long-standing medieval penchant for ordering information on a rational basis, such as by hierarchy of authority, proved insufficient for the compilation of indexes. As the Rouses point out, for medieval scholars, the universe was an ordered whole whose constituent parts were designed by God to be in harmony. Each of these parts related to others, and "it was the responsibility of the author or scholar to discern these rational relationships-of hierarchy, or of chronology, or of similarities and differences ... and to reflect them in his writing." ${ }^{16}$ But it was precisely the alphabetical organizational schema that not only would be required for the production of effective searching tools, but would be fitfully accepted during the course of the thirteenth century.

\section{Cross-Referencing}

There exists a rudimentary form of cross-referencing, and it occurs repeatedly in the index to Casanatensis 1730. Though entries are phrases generally arranged alphabetically by an initial topical keyword, the index is not always strictly alphabetized within its subdivisions, and the alphabetical order is sometimes interrupted by a change of tense, case, or number of a Latin word within a category. The index is alphabetical up to the concept level since within a range for a given initial letter, there is a sequence of topical categories. For instance, under headings beginning with $S$, in figure 5 , the index has topics, some with multiple subdivisions, that are ordered alphabetically: Sacerdos, Sacramentum, Sacros, Satisfactio, Sententia, Sepultura, and

15 Rouse and Rouse, "Statim invenire," 204, n. 10.

16 Rouse and Rouse, "Statim invenire," 211. 


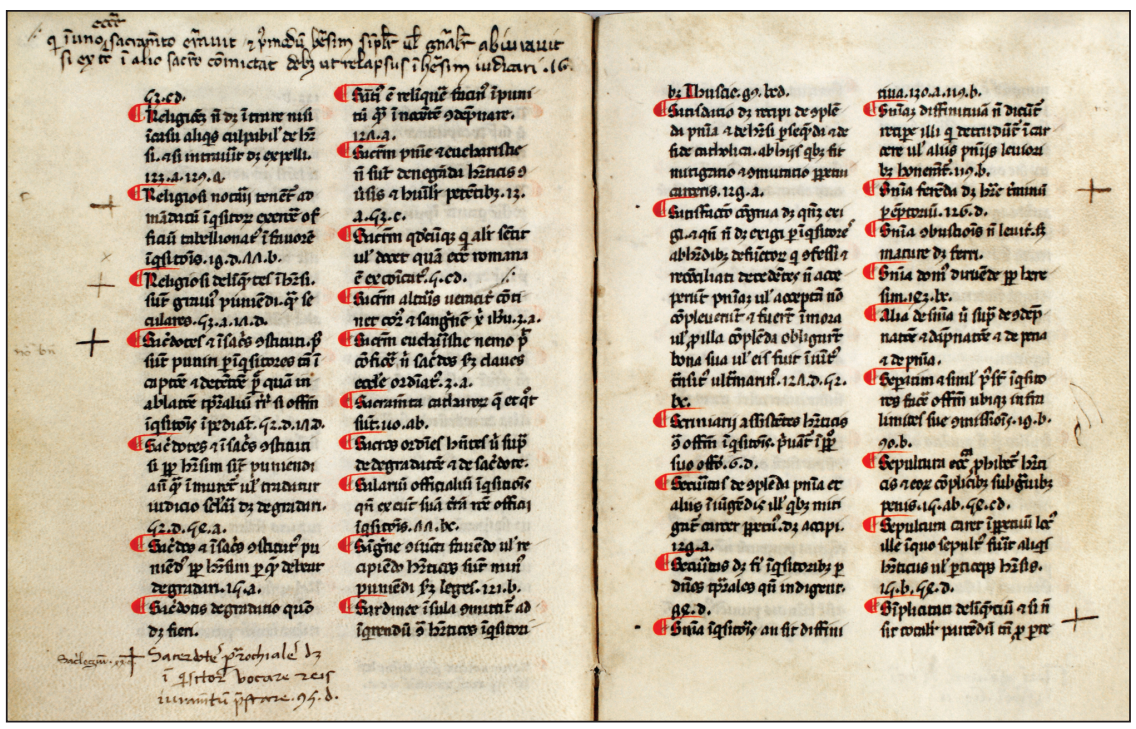

FIGURE 5. Rome, Biblioteca Casanatense MS 1730, fols. 33v-34r.

so on. ${ }^{17}$ Within any given topic, such as sacerdos in figure 6 , full alphabetical order throughout the word's variants and subtopics is not strictly observed. ${ }^{18}$ Likewise, in the section concerning "seizures" in figure 7 , the initial keywords are Capere, Capi, Capere, Captum, Capientes, and finally Alia de captione. ${ }^{19}$

This last entry beginning with Alia de captione, out of strict order by its initial, but within the alphabetical range for the topic, which is captione and not alia, is a cross-reference directing the reader to another section of the index for more information. In this instance, the full entry reads: "Alia de captione hereticorum ubi infra in officialibus inquisitoris." ${ }^{20}$ For additional reference and information, one was directed to the section dealing with officiales of the inquisitor, which is indeed relevant. ${ }^{21}$

17 Casanatense 1730, fols. 33va-34rb.

18 The four entries for Sacerdos in Casanatense 1730, fol. 33va begin: Sacerdotes . . ; Sacerdotes ...; Sacerdos . . ; Sacerdotis ....

19 Casanatense 1730, fol. 4va-b.

20 Casanatense 1730, fol. 4vb.

21 Casanatense 1730, fol. 28ra-va. 


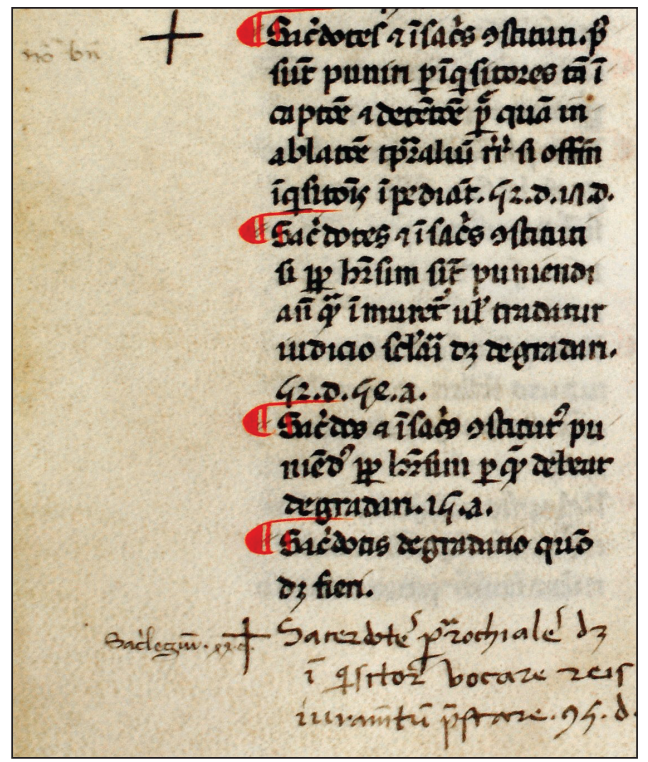

FIGURE 6. Rome, Biblioteca Casanatense MS 1730, fol. 33va.

\begin{tabular}{|c|c|}
\hline 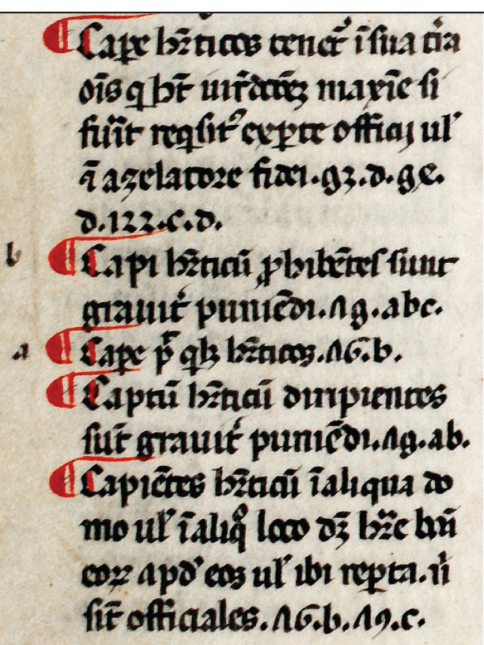 & $\begin{array}{l}\text { Capere hereticos tenetur in sua terra } \\
\text { omnis qui habet iurisdictionem maxime si } \\
\text { fuerit requisitus ex parte officii vel } \\
\text { etiam a zelatore fidei.83.d.84 } \\
\text { d. } 122 . \text {.c.d. } \\
\text { Capi hereticum prohibentes sunt } \\
\text { graviter puniendi. } 78 \text {.abc. } \\
\text { Capere potest quilibet hereticos. } 76 . b . \\
\text { Captum hereticum diripientes } \\
\text { sunt graviter puniendi. } 78 \text {.ab. } \\
\text { Capientes hereticum in aliqua do- } \\
\text { mo vel in aliquo loco debent habere bona } \\
\text { eorum apud eos vel ibi reperta.nisi } \\
\text { sint officiales. } 76 . \text { b.79.c. }\end{array}$ \\
\hline $\begin{array}{l}\text { iflis } \\
\text { ifi: }\end{array}$ & $\begin{array}{l}\text { Alia de captione hereticorum ubi } \\
\text { infra in officialibus inquisitoris. }\end{array}$ \\
\hline
\end{tabular}

FIGURE 7. Rome, Biblioteca Casanatense MS 1730, fol. 4va line 14-4vb line 2. 
Such cross-references, of which there are twenty-one, always start with alia. They appear occasionally in the middle of a string of entries relating to a topic, but are more often placed at the end of a sequence of related entries. Depending on where the reference appears, it directs the reader either supra or infra-above or below-for more information. In some instances, the cross-reference directs the reader to more than one spot for further consultation. For example, on folio 9rb, in the section of the index dealing with believers of heretics, an entry reproduced in figure 8 directs the reader both above and below for more information. The entry itself is at the end of the sequence on believers, or credentes, and reads: "Alia de credentibus supra in bonis, infra in hereticis." 22 A related point on cross-referencing also involves the word capere. As figure 9 (my full-length transliteration of the original abbreviated Latin) indicates, it need not have the seizure of heretics (capere hereticorum) as the principal topic, but refers to any number of subjects or issues related to seizing heretics. An inspection of this part of the index bears out this point. All the entries in this section pertain in some fashion to seizure, but as capere is a verb, the subjects of the index entries vary and thereby address quite differing issues related to seizing people or their goods.

The main point of the first entry, Capere hereticos, is that all those who have jurisdiction in their land are bound to seize heretics, especially if they are required to do so on the part of the office of the inquisition, or even by one zealous for the faith. This is immediately followed by an entry, Capi bereticum, warning that those prohibiting the seizure of a heretic are to be punished severely. Furthermore, after stating in the next entry, Capere potest, that anybody can seize heretics, the item immediately after that, Captum bereticum, warns that those who snatch away a captured heretic are also to be gravely punished. Despite the emphasis on the inquisition, most of the topical entries concern the obligations of locals in seizing heretics, and harsh punishment for those who thwart or undermine such arrests. The duties of actual inquisitorial officials in this regard are detailed elsewhere in the index, as the closing reference, alia de captione, makes clear.

22 Casanatense 1730, fol. 9rb. 


\section{Mlua cerractubs $\$$ ilomis. Alia de credentibus supra in bonis i. ilstuas infra in hereticis}

FIGURE 8. Rome, Biblioteca Casanatense MS 1730, fol. 9rb, lines 15-16.

$$
\begin{aligned}
& \text { Capere hereticos tenetur in sua terra omnis qui habet } \\
& \text { iurisdictionem maxime si fuerit requisitus ex parte officii vel } \\
& \text { etiam a zelatore fidei.83.d.84.d.122.c.d. } \\
& \text { Capi hereticum prohibentes sunt graviter puniendi. 78.abc. } \\
& \text { Capere potest quilibet hereticos. 76.b. } \\
& \text { Captum hereticum diripientes sunt graviter puniendi. 78.ab. } \\
& \text { Capientes hereticum in aliqua domo vel in aliquo loco debent } \\
& \text { habere bona eorum apud eos vel ibi reperta.nisi sint officiales. } \\
& 76 . b .79 . c . \quad \text { End fol. } 4 \mathrm{va} \\
& \text { Alia de captione hereticorum ubi infra in officialibus inquisitoris. }
\end{aligned}
$$

FIGU RE 9. Rome, Biblioteca Casanatense MS 1730, fol. 4va, line $14-4 \mathrm{vb}$, line 2.

An even greater range of subtopics and issues appears in the index in figure 10 among the entries under the initial word bona (goods) and its variants. ${ }^{23}$ These range from the disposition of goods of the deceased who were condemned, who completed their sentence while still alive, or who failed to satisfy their penances in life; to the sale of confiscated goods-by whom and within what time frame- to the division of the proceeds accruing from the confiscation and sale of goods, and several other topics. Of course, the range of issues addressed for some topics in the index, such as that concerning goods, is more comprehensive than for others. In those instances where there is less thorough treatment of a topic, like seizure, cross-references are usually included at the end of a topic's sequence of index

23 Casanatense 1730, fol. 3va-4rb. 


\begin{tabular}{|c|c|c|c|c|}
\hline 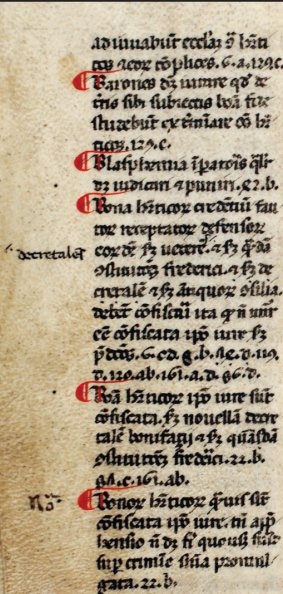 & 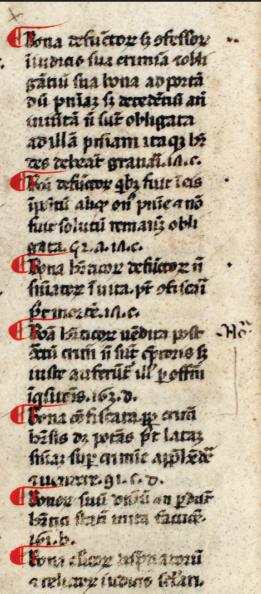 & 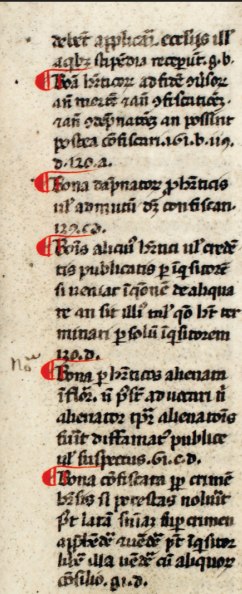 & 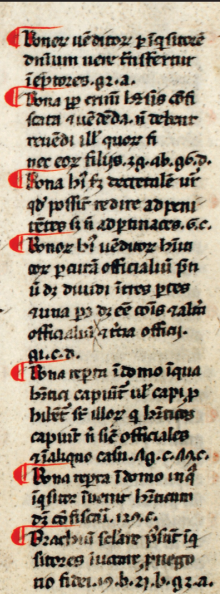 & 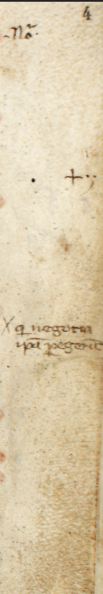 \\
\hline
\end{tabular}

FIGURE 10. Rome, Biblioteca Casanatense MS 1730, fols. 3va, line 9-4rb, line 24.

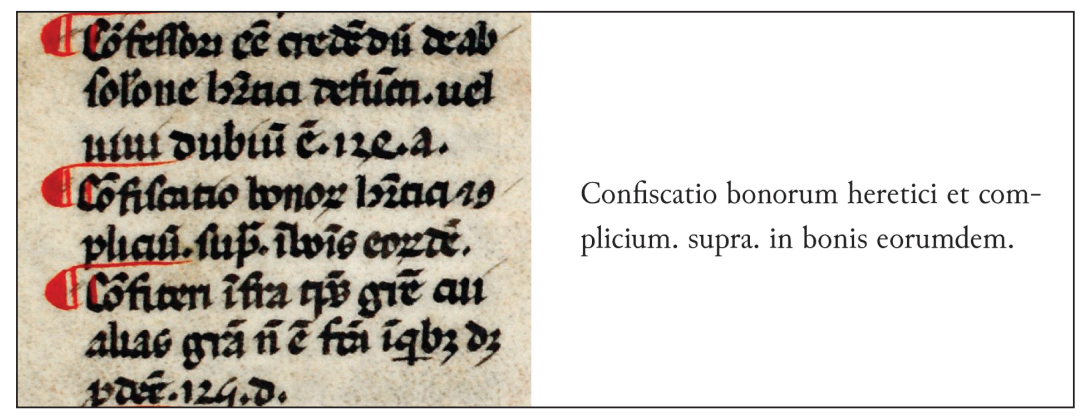

FIGURE 11. Rome, Biblioteca Casanatense MS 1730, fol. 7va, lines 13-19.

entries to direct the reader elsewhere for more information. This is the case for capere, but not for bona. Conversely, in the case of bona, isolated crossreferences appear in appropriate alphabetical spots throughout the index directing the reader back to this comprehensive list of entries concerning bona. A case in point is the entry for confiscatio. In figure 11, one can see that there is only one entry consisting of two lines for this keyword, and it is a cross-reference directing the reader above to the section on bona. ${ }^{24}$ There is

24 Casanatense 1730, fol. 7va; "Confiscatio bonorum heretici et complicium supra in bonis eorumdem." 
also a subtler method integrated into the index to cross-reference issues or topics. One could liken it in structure to a modern multi-phase personality inventory often used in psychological tests whereby the same issue or question is posed multiple times in separate questions of the exam but is worded quite differently in each instance.

For example, in Casanatensis 1730's index, the point of having separate and hidden rooms or cells for imprisoned heretics is stated no less than three times in the index under three completely different topical keywords. The first instance occurs on folio 4va (figure 12), which reads: "Camerule separate et occulte debent esse in carcere inquisitionis ita quod heretici et ab aliis malefactoribus et a se invicem sequestrati maneant. 128.b." ${ }^{25}$ A little further on in the section concerning prison, figure 13 shows another entry that reads: "Carceres pro hereticis tenendis debent esse separati a carceribus aliorum malefactorum et in se habere distinctas camerulas.128.b." ${ }^{26}$ Finally, an entry appearing in the section concerning immuration in figure 14 reads: "Inmurandis hereticis debent fieri carceres cum camerulis distinctis et occultis in qualibet civitate suspecti de heresi.128.b." ${ }^{27}$ All three entries concern the sequestration of those imprisoned for heresy from other inmates and specify that there must be designated rooms set aside for their incarceration. In all three entries, the alphanumerical reference directs the reader to the same column and folio (fol. 128.b, or fol. 168rb in the modern reckoning), which is a consilium from the provincial council of Béziers of the archbishop of Narbonne and his suffragan bishops as to how one may proceed in an inquisition.

There are multiple examples of this type of topical duplication in different sections of the index. Clearly, the author of the index approached his work in a highly systematic and methodical manner and included what he must have considered particularly important points under different headings. In the event a user could not find what he was looking for in one spot where it may occur to him to search, he would find it in

25 Casanatense 1730, fol. 4va.

26 Casanatense 1730, fol. 5ra.

27 Casanatense 1730, fol. 20ra. 
Manuscript Studies, Vol. 2 [2018], Iss. 2, Art. 1

Clement, Statim prosequi

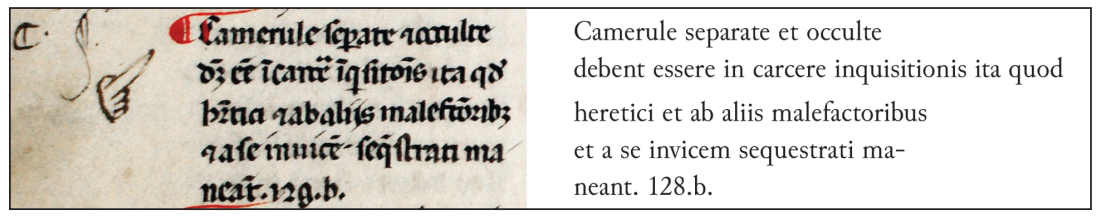

FIGURE 12. Rome, Biblioteca Casanatense MS 1730, fol. 4va, lines 9-13.

\begin{tabular}{|c|c|}
\hline 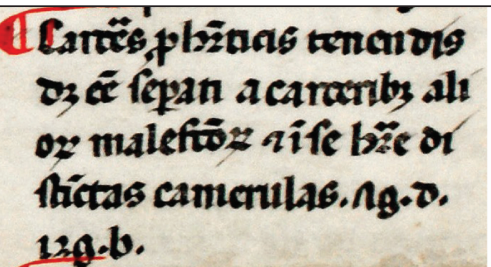 & $\begin{array}{l}\text { Carceres pro hereticis tenendis } \\
\text { debent esse separati a carceribus ali- } \\
\text { orum malefactorum et in se habere di- } \\
\text { stinctas camerulas. } 78 . \text { d. } \\
\text { 128.b. }\end{array}$ \\
\hline
\end{tabular}

FIGURE 13. Rome, Biblioteca Casanatense MS 1730, fol. 5ra, lines 20-24.

\begin{tabular}{|c|c|}
\hline 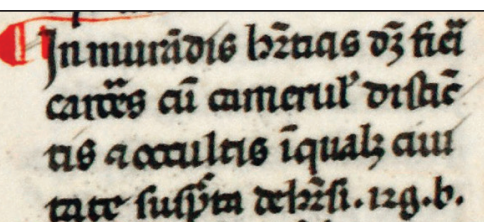 & $\begin{array}{l}\text { Inmurandis hereticis debent fieri } \\
\text { carceres cum camerulais distinc- } \\
\text { tis et occultis in qualibet civi- } \\
\text { tate suspecti de heresi.128.b. }\end{array}$ \\
\hline
\end{tabular}

FIGURE 14. Rome, Biblioteca Casanatense MS 1730, fol. 20ra, lines 18-21.

another that makes equal sense or he would find a cross-reference directing him elsewhere for more information. This also means that there was no universally accepted way of describing some situations-that is, there was no standardized jargon yet that encapsulated the possible terminological approaches of a user, and so the author had to try to anticipate some of the various and flexible ways of describing topics. That there is a degree of fluidity in describing topics means that all of the features of a precise and unambiguous technical language had not yet developed. This brings us to the next major point concerning the content of many index entries. 


\section{Index Entries as Distilled Summaries of Law, Powers, or Procedures}

Alphabetization, Arabic numerals, and cross-referencing are certainly noteworthy characteristics of the index in Casanatensis 1730. But the compositional structure of many index entries — what they actually say—is particularly striking. In the overwhelming majority of topical listings in the index, the entries are not simply a word or two with appended page numbers for more information. Rather, they are whole sentences or even short paragraphs. As figure 15 shows, these lengthy entries in the index make statements that are more like brief summaries of an issue, power, or procedure rather than a simple index listing with corresponding folio reference for further information. Of course, nearly all index entries are followed by the referential folio numbers and columnar letters that correspond to the relevant parts of full-length documents that are contained within the main body of the codex.

It is certainly likely that the index served as one might expect, as a guide to full authorities or explications on a topic, but also that many entries functioned in their own right as brief summaries of the law from which an active inquisitor was able to benefit immediately. In this sense, an interpretive and editorial process was under way in the composition of many index entries. What is more, the documents to which the index entries refer are being treated in a distilled or decontextualized way by the composer of the index - almost as a footnote to the index entry rather than vice versa. Once something is law, or issued by an authority and listed in the body, the writer assumed that the user would want to know first what its conclusions are, even if excerpted from the middle of a longer text. Such a relation to authority was not alien to clerics trained in exegesis and the analysis of lemmas. Some concrete examples will help to illustrate this point.

On folio 1va of the index, there are two entries that both begin with the word absolvere. Figure 16 contains the first, and it reads: "Absolvere possunt inquisitores a maiori excommunicatione suspensione et interdicto illos qui assument crucem contra hereticos. 62.b."28

28 Casanatense 1730, fol. 1va. 
Manuscript Studies, Vol. 2 [2018], Iss. 2, Art. 1

Clement, Statim prosequi

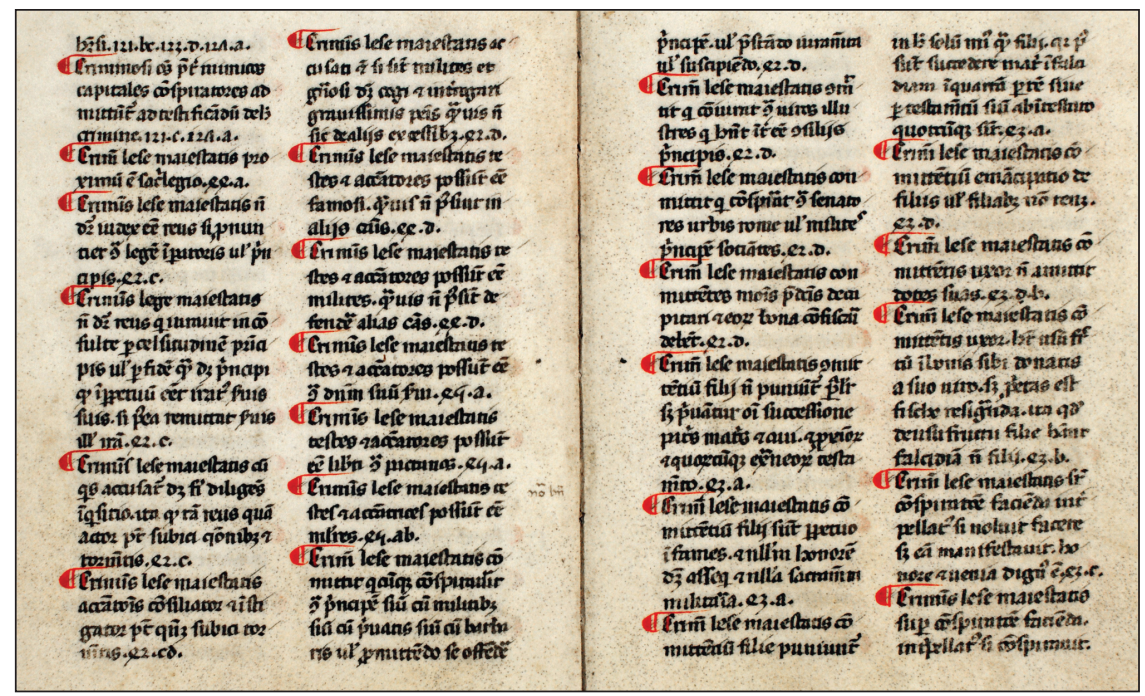

FIGURE 15. Rome, Biblioteca Casanatense MS 1730, fols. 9v-10r.

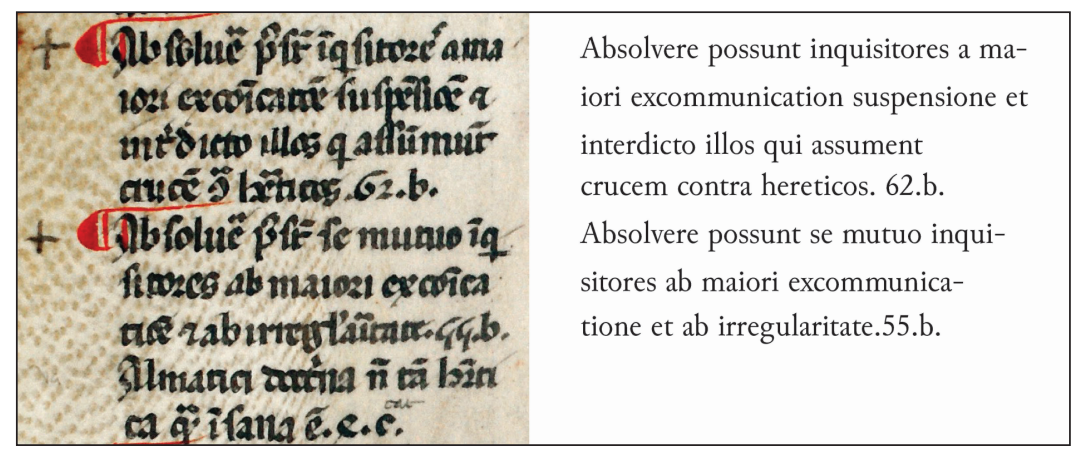

FIGURE 16. Rome, Biblioteca Casanatense MS 1730, fol. 1va, lines 10-18.

This is immediately followed by an entry that reads: "Absolvere possunt se mutuo inquisitores ab maiori excommunicatione et ab irregularitate 55.b." ${ }^{29}$ The first instance simply informs the user that inquisitors can absolve from excommunication, suspension, or interdict of all those who take up the cross against heretics (a euphemism for crusading), and the 
second entry tells him that inquisitors can absolve each other from excommunication or canonical irregularity. In neither case is it absolutely necessary to go to the folios cited since the index entry states the essential matter at hand-who can absolve whom, from what, and for what reason.

Another sequence of examples relates to apostates from the faith. Figure 17 contains a series of statements regarding those who have apostatized. It is comprehensive enough to make moot an actual consultation of the portion of the Corpus Iuris Civilis contained in the body of the codex proper to which the entries refer the reader. In all four instances, the entries succinctly summarize or make a statement about how apostates should be treated by the law: they must be segregated from any association or fellowship, they cannot be witnesses for another's oath, they cannot inherit or be designated as heirs, and they can never revert to pristine canonical status owing to their prior rejection of the faith.

The entries are often appropriate as standalone guides. In the aforesaid part of the index concerning goods (bona), figure 18 contains an entry that reads: "Bona confiscata propter crimen heresis si potestas noluerit post latam sententiam super crimen apprehendere et vendere potest inquisitor libere illa vendere cum aliquorum consilio. 81.d." ${ }^{30}$ In this instance, as in many others in the index, the subject is not the goods per se, but the time period within which they were to be sold. Additionally, this entry specifies that if the podestà is unwilling to do this, then the inquisitor may do so with the advice and counsel of others. These index entries are more than simple references to documents within the codex from which a reader may obtain more information. They are summaries, and there are dozens of entries structured this way in the index.

Such references show how the index could have stood as an independent work. Clearly the original writer who produced it did so in a way that reflected his thinking on the law. Thus, the main body of the codex contains texts or extracts therefrom, but the index was designed as one arranged alphabetically by topic. Within the treatment of each topic, there are usually entries that summarize the law or one's status, rights, privi-

30 Casanatense 1730, fol. 4ra. 


\begin{tabular}{|c|c|}
\hline 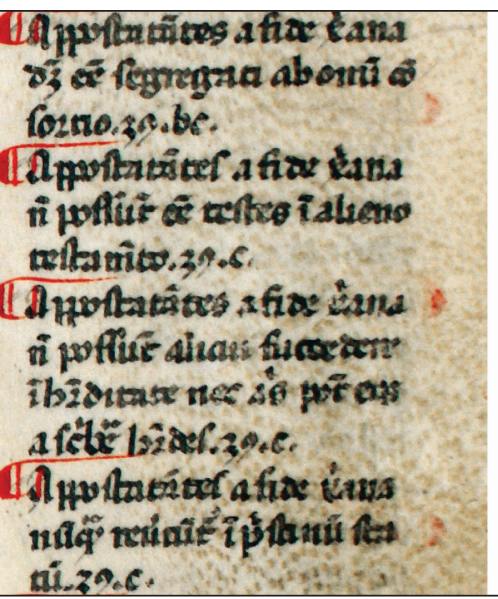 & $\begin{array}{l}\text { Appostatantes a fide Christiana } \\
\text { debent esse segregati ab omni con- } \\
\text { sortio. 39.bc. } \\
\text { Appostatantes a fide Christiana } \\
\text { non possunt esse testes in alieno } \\
\text { testamento.39.c. } \\
\text { Appostatantes a fide Christiana } \\
\text { non possunt alicui succedere } \\
\text { in hereditate nec aliis possunt eos } \\
\text { ascribere heredes. 39.c } \\
\text { Appostatantes a fide Christiana } \\
\text { numquam revertuntur in pristinum sta- } \\
\text { tum. 39.c. }\end{array}$ \\
\hline
\end{tabular}

FIGURE 17. Rome, Biblioteca Casanatense MS 1730, fol. 2rb, lines 4-16.

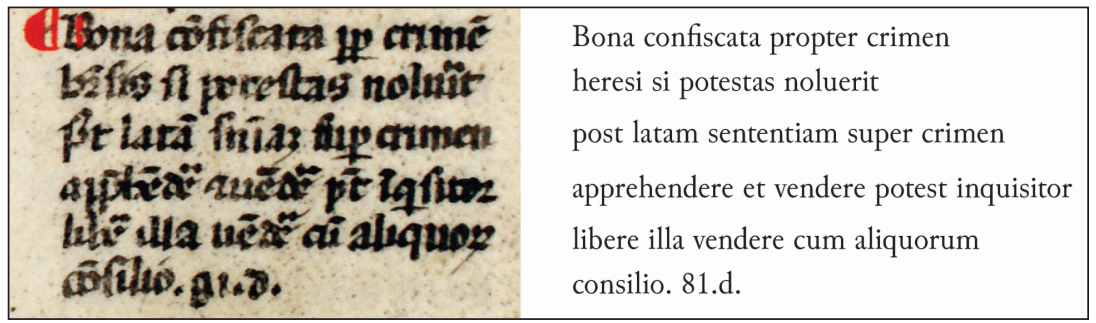

FIGU RE 18. Rome, Biblioteca Casanatense MS 1730, fol. 4ra, lines 22-27.

leges, and prohibitions arising from the texts contained more extensively in the main body of the codex. What is more, even though laws and decretals were included selectively in Casanatensis 1730, the index writer parsed the itemized relevance of these longer documents by breaking their contents into bits and pieces, arranging them in the index alphabetically by topic, and then referring the reader to the full-length text in the codex so that the reader could consult the law or decretal in question, or find an authority for the index entry. Reading the body of the collection was not, however, essential since the index entry furnished the reader with many answers to questions, problems, or issues that the original writer tried to anticipate in his work. 


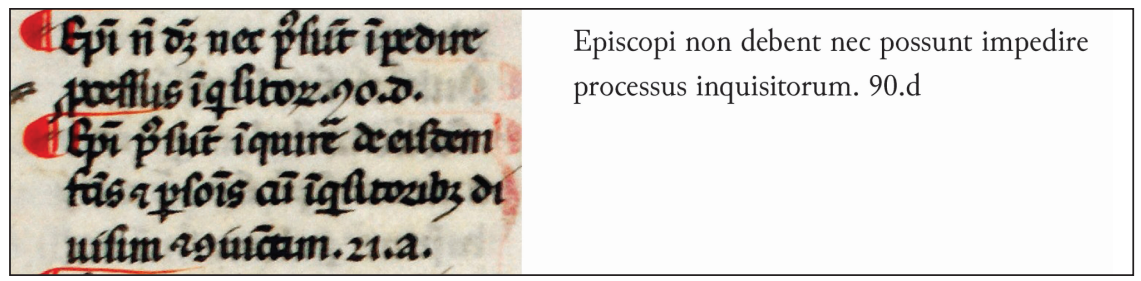

FIGURE 19. Rome, Biblioteca Casanatense MS 1730, fol. 13va, lines 6-10.

Finally, in spots there is evidence of an intermediate editorial or interpretive step in the compilation of the index. For instance, figure 19 contains an entry from folio 13va that reads: "Episcopi non debent nec possunt impedire processus inquisitorum. 90.d." The entry refers to a passage in a decretal of Clement IV, Licet ex omnibus. ${ }^{31}$ On folio $130 \mathrm{vb}$ of that decretal, figure 20 contains the text that reads "nec pretextu commissionis specialiter eisdem dyocesanis super hoc facte vestros processus in eorumdem dyocesanorum civitatibus et diocesibus volumus impediri." It should be noted that although the index item is Episcopi, the word episcopi does not appear in the text on folio $130 \mathrm{vb}$, although dyocesanis does. This is yet another indication that the index is interpretive in that it not only is based on rubrics, incipits, or simple keywords, but contained editorial interpretive steps in its composition.

Taken as a whole, these characteristics of cross-referencing and index entries that summarize or distill the laws, powers, and procedures relating to inquisitorial authority and activity were intended to facilitate an inquisitor in consulting and informing himself on the spot of a variety of scenarios, such as how different classes of defendants should be treated, who may testify and under what circumstances, how their testimony was to be handled, and where and by whom papal and imperial constitutions should be aggregated with extant municipal law books or codes, while at the same time enabling an inquisitor to bypass the authoritative texts to which the index entries all made reference. Finally, the practical and utilitarian nature

31 Casanatense 1730, 130ra-133va. 


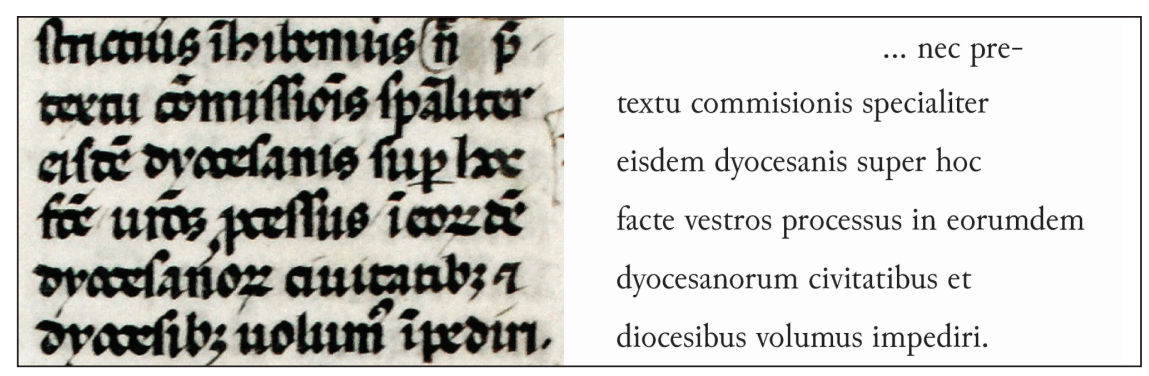

FIGURE 20. Rome, Biblioteca Casanatense MS 1730, fol. 130vb, lines 3-8.

of Casanatensis 1730's index is reflected in the greater frequency of marginalia in the index rather than the main body of the codex.

\section{Symbols}

That the codex was practical in nature and in continual use for some time is indicated by the repeated appearance of marginal symbols throughout the manuscript. As can be seen in figure 21, there are at least seven types of marginalia used by inquisitors to highlight certain materials in Casanatensis 1730. Among these categories, there are variants that indicate different notaries, scribes, or inquisitors using similar symbols to bookmark the information that they needed. Figures 22 and 23 show many of the seven categories of marginal symbols I have identified. These are black crosses, abbreviations for nota bene, hands with pointing fingers, two horizontal dots with a vertical line between them and extending below, two horizontal dots with a vertical line extending below and curving to the left at the end, a symbol that resembles the Arabic numeral two, and the letter F. Within each of these categories, save for the letter F, there are variants in size, intensity of color, and style. In the case of the abbreviations for nota bene, there are also variants in that some are abbreviated no, others no bn, with different hands for each.

The category in which one can most readily detect obvious differences is the hand with a pointing finger. Among these symbols there are at least six variants, and each one repeats two times or more in the codex. In some 


\section{0 | Journal for Manuscript Studies}

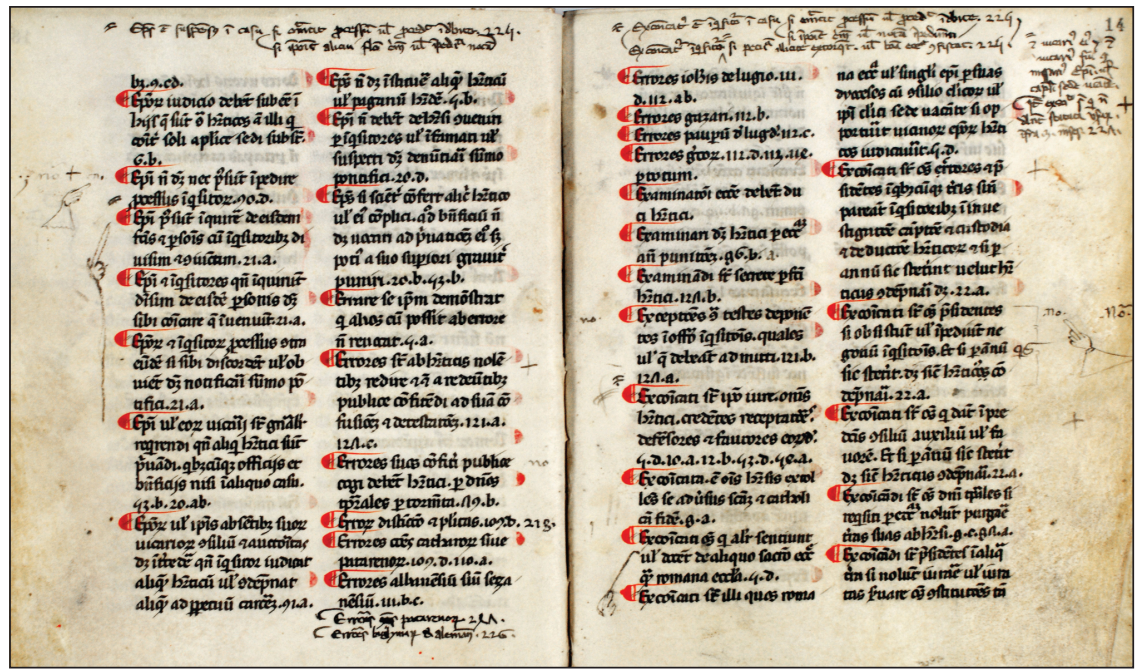

FIGURE 21. Rome, Biblioteca Casanatense MS 1730, fols. 13v-14r.

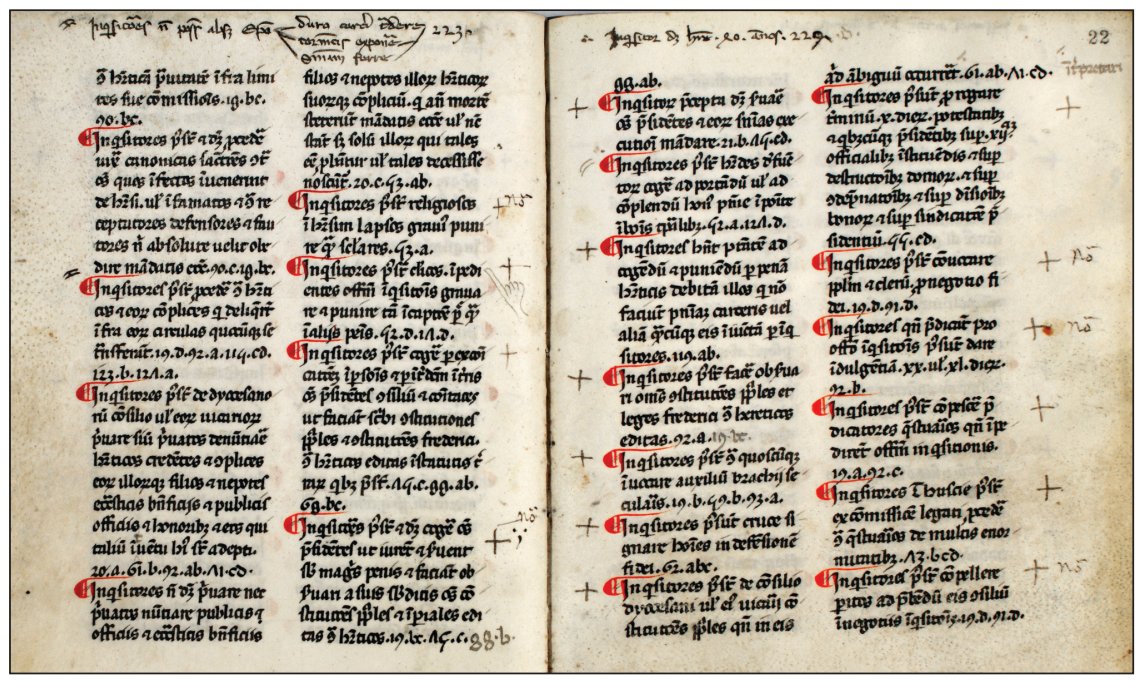

FIGURE 22. Rome, Biblioteca Casanatense MS 1730, fol. 21vb-22rb. 
Manuscript Studies, Vol. 2 [2018], Iss. 2, Art. 1

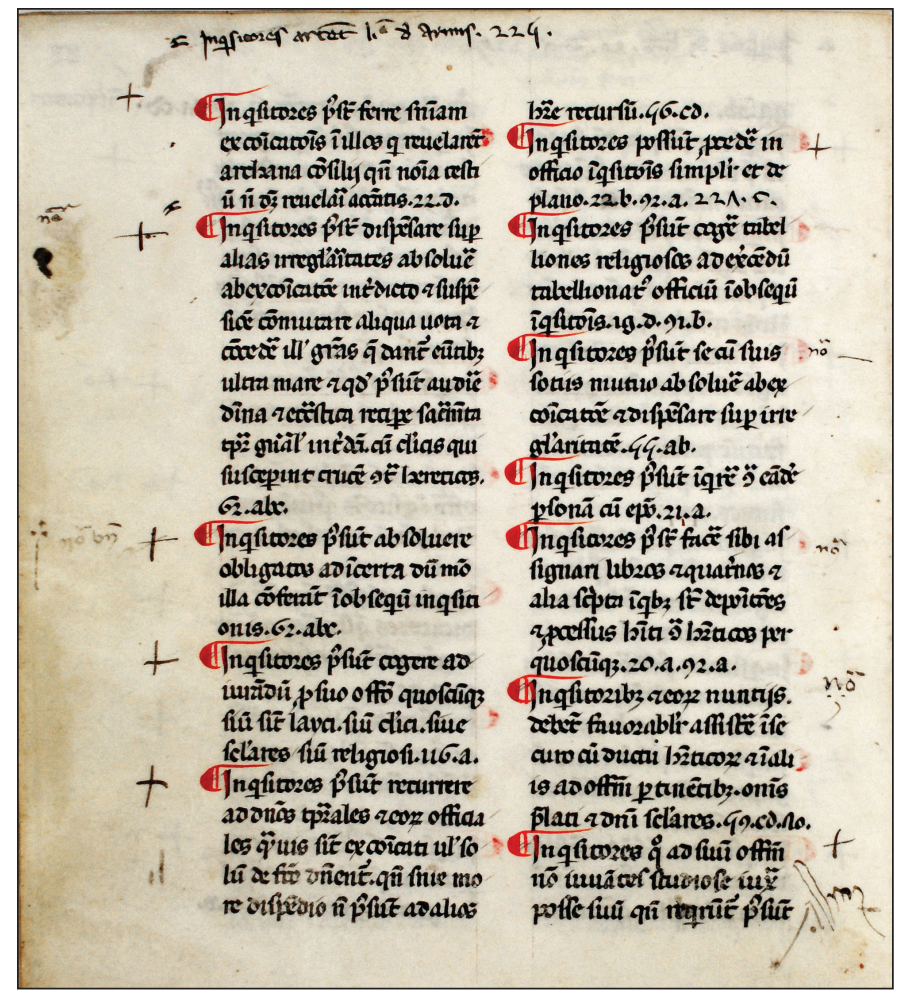

FIGURE 23. Rome, Biblioteca Casanatense MS 1730, fol. 22v.

instances, symbols from multiple categories appear next to the same passage of text. This indicates that the topic of the highlighted text under consideration was repeatedly an issue for different inquisitors over the duration of the codex's utilitarian life. To return to folio 13va concerning the prohibition of episcopal interference in inquisitorial processes, figure 24 contains the index entry that reads: "Episcopi non debent nec possunt impedire processus inquisitorum. 90. D." ${ }^{32}$ It is marked with No $+t a$, a hand with pointing finger, and two dots with a curved vertical line. These symbols occur far more frequently in the index than in the main body of the codex. In numerous places in the index where a marginal symbol appears, 


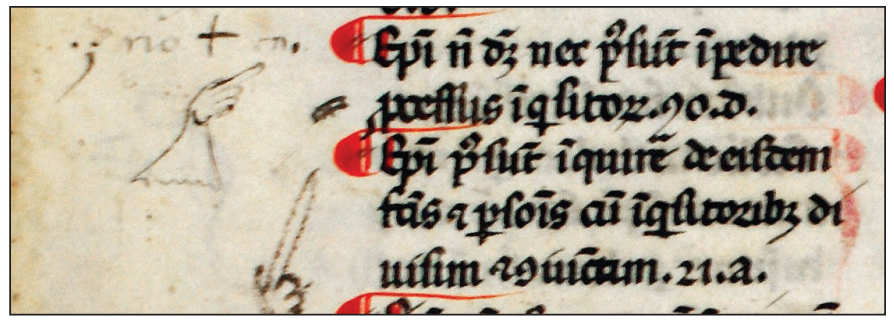

FIGURE 24. Rome, Biblioteca Casanatense MS 1730, fol. 13va, lines 6-10.

no corresponding symbol, or no symbol at all, appears on the folio number to which the index entry was directing the user. The presence of annotations in the index without corresponding notes in the text, together with the wording of many index entries, supports the possibility that index entries served as brief, almost independent, summaries of powers or procedures that an active inquisitor could consult quickly when necessary.

Use as a quick reference guide, as well as an index proper, may explain the many marginal symbols that appear in the index, but not on the folios to which the index entry and its marginalia refer. This is particularly the case with the black crosses, reproduced in figure 25 , as there are far more of these in the index than elsewhere in the codex. Furthermore, nowhere in the index is a specific bull or other document named. Unlike court cases where opposing parties cite evidence, inquisitors need only know the procedure and have confidence in their authority. The index provides the former, the references to original texts the latter, but the inquisitors did not need to cite the original texts, and so authorities could be omitted from the topical "handbook," as it appears that was how the index functioned. It summarized inquisitors' rights, procedures, and reasons why a person, who may not even be a heretic, may be punished by him. That it also served in part as an index for fuller study is possible, but may not have been its first purpose.

Such a volume must have been difficult to consult for inquisitors, who may have been less concerned with citations and context than they were with practice and procedure. Neither the index nor the main body of the manuscript is arranged by incipits, individual authors, or dates. Codex Casanatense's practical use in the field is made manifest by the marginal 


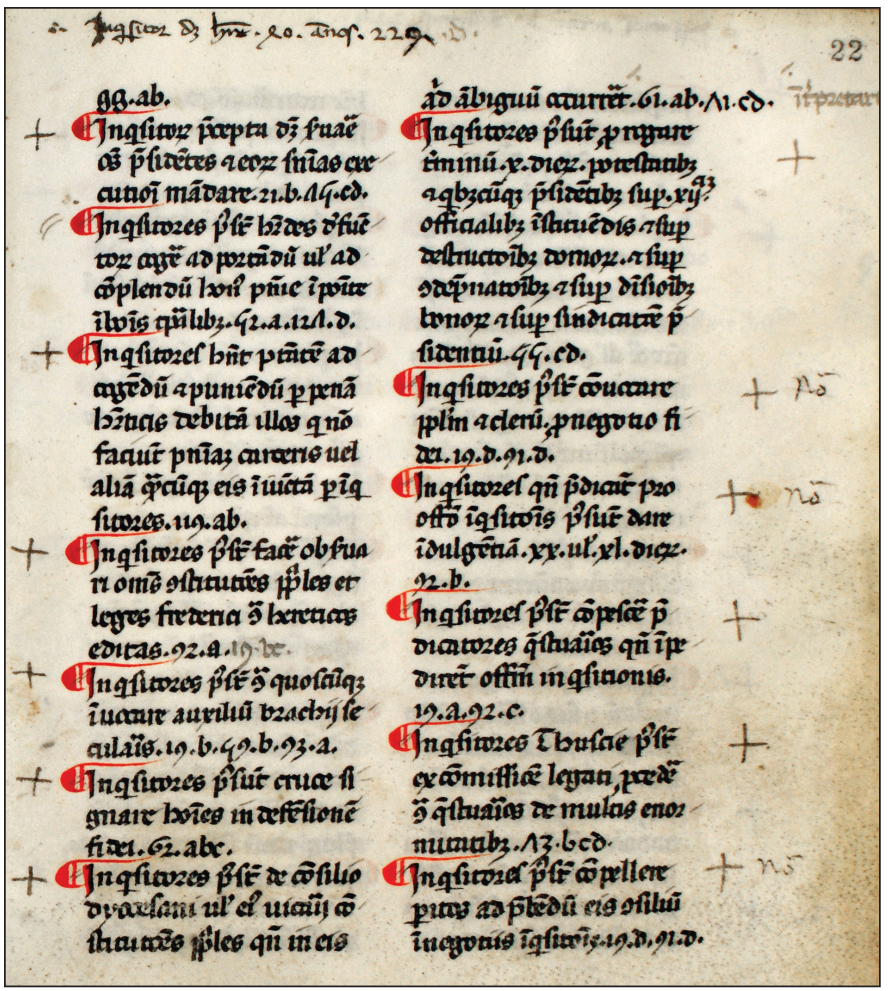

FIGURE 25. Rome, Biblioteca Casanatense MS 1730, fol. 22r.

markings of varying types. Different inquisitors used this book in the course of conducting their inquiries, and for each inquisitor, there were differing issues that were of greater or lesser importance to them at any given point. The recording of pertinent extracts from conciliar decrees and papal bulls shows that the production of this work was not simply slavish copying of materials in their entirety, but an active process of including information as needed for the purposes to which it was dedicated. Editorial selectivity is especially reflected in materials unique to Casanatensis 1730 that are not found in other collections, such as those texts that concern Franciscans and interpretations of Franciscan rules as they may apply to inquisitors. But Casanatensis 1730 also shares a number of materials in common with other inquisitorial collections, such as the canons of the council of Toulouse and many papal bulls that appear in the codex. 
To summarize and conclude, the length of the work and the breadth of the materials contained in Casanatensis 1730 indicate that the original writer may have intended this to be an encyclopedic reference work covering all possible legal and procedural bases. It is, however, selective, and small enough to be completely portable, an important consideration for itinerant inquisitors. The more convenient and useful textual weapon for the inquisitor was the index-that alphabetically arranged mini-libellus that comprised thirty-seven folios of a work that ultimately contains 297 folios, and that set forth the duties, powers, procedures, possible penalties, and categories of defendants and how they should be treated, that were within an inquisitor's purview. The index was deliberatively composed in a form whereby full-length legal texts were parsed, distilled, and summarized by the original writer in anticipation of his work being used in the field perhaps by himself and likely others as well. The full-length legal texts in the codex become footnotes to the index-a reversion of what one might expect. Thus it was not only a summary of authoritative lengthy legal texts contained in extensu within the codex, but one that was easily accessible and readily consultable, and the entire codex was wholly portable.

That Codex Casanatensis 1730 was produced and used by inquisitors as outlined above is reflected in the far greater abundance of marginalia in the index. Marginal markings and symbols were later added by different users to highlight what they thought of as particularly important, or perhaps the issues with which they were contending in a given time and place. While the same marks also appear in the main body of the codex, they appear far less frequently. This indicates that the index was consulted more often than the main body of the codex and that the full-length legal texts were more of an afterthought to a practicing inquisitor. It appears that an inquisitor could consult imperial laws, conciliar decrees, or papal constitutions if he liked or needed, but more often the index summaries sufficed for his purposes while using the codex.

Finally, it should be borne in mind that Codex Casanatensis 1730 was never a work that was intended to be read from beginning to end. Instead, it was an inquisitorial legal reference work whose encyclopedic contents were ingeniously reduced to index entries composed of summary sentences and paragraphs to which inquisitors could quickly and easily refer. It is espe- 
Manuscript Studies, Vol. 2 [2018], Iss. 2, Art. 1

cially in this sense that the manuscript was the medium by which the medieval inquisition, less than a century after its initiation by Pope Gregory IX, was able not only to produce such a text in what was an entirely heretofore unknown literary genre-that of inquisitors' manuals-but to make effective use of such an instrument in the quotidian performance of inquisitorial duties. The index portion of Codex Casanatensis 1730 was a product, an instrument, and the medium by which a voluminous and complex body of legal texts was reduced to its essentials and rearranged into a form that could be accessed quickly and easily—statim prosequi-by anyone in need of such a handy reference guide. 


\section{List OF MANUSCRIPTS CITED}

Baltimore, Walters Art Museum

W 751: 451, 470

W 759-62: 474

W 777: 473

Bangkok, Wat Hua Krabu

Manuscript: 431, 432 fig. 1

Berlin, Staatsbibliothek

HS 241: 480

Birmingham, Barber Institute

No. 397: 479

Boston, Boston Public Library

MS 1532: 473

Brussels, Bibliothèque Royale

MS IV 191: 481

MS IV 542: 478

Bryn Mawr, PA, Bryn Mawr College

Gordan MS 95: 527-28, 527 fig. 1, 528

nn. $15-16$

Cambridge, MA, Harvard University,

Houghton Library

MS Richardson 17: 482

MS Richardson 26: 471

MS Typ 141: 476

MS Typ 143: 480

MS Typ 200: 472

MS Typ 201: 474

MS Typ 202: 472

MS Typ 213: 478

MS Typ 217: 482

MS Typ 228: 474

MS Typ 703: 476
Cambridge, UK, Corpus Christi College

MS 4: 585

MS 32: 338, 338 n. 25, 343 n. 34, 355 n. 61

Cambridge, UK, Fitzwilliam Museum

MS 251, fol. 15r: 585

MS 276: 586

MS 159: 587

MS 330: 472, 585

MS 375: 462, 478

Collegeville, MN, Saint John's University,

Ethiopian Manuscript Microfilm Library

MS no. 4553: 414 n. 69

Cologne, Historisches Archiv

Best. 7010-293: 585

Cologny, Fondation Martin Bodmer

Cod. Bodmer 14 : 476

Cod. Bodmer 68: 470

Cod. Bodmer 104: 480

Cod. Bodmer 128: 481

Cod. Bodmer 139: 481

Cod. Bodmer 183: 474

Dublin, Chester Beatty Library

Thai MS 1341: 432

Thai MS 1343: 433

W 017: 471

W 029: 471

W 040: 472

W 043: 472

W 061: 474

W 066: 474

W 076: 457 fig. 3, 475

W 078: 475 
Manuscript Studies, Vol. 2 [2018], Iss. 2, Art. 1

\section{Journal For Manuscript Studies}

W 080: 475

W 082: 453, 454 fig. 1, 458, 479

W 089: 478

W 094: 479

W 099: 482

W 107: 477

W 108: 477

W 113: 477

W 122: 477

W 124: 476

W 127: 476

W 188: 480

W MS 103 (formerly; now dismembered): 455 fig. 2, 456

Dunhuang

Nai 93: 499, 502-7, 503 n. 8

Tama 24: 499, 502-7, 503 n. 8

Florence, Bibl. Medicea Laurenziana

MS Or. 148: 423

Geneva, Bibliothèque de Genève

Comites Latentes MS 15: 474

Comites Latentes MS 38: 479

Ghent, Universiteitbibliotheek

MS 92: 569

Göttingen, Niedersächsische Staatsund-Universitätsbibliothek

MS Uffenb. 51 cim.: 585

The Hague, Koninklijke Bibliotheek

MS 135 E 23: 478

MS 135 J 8: 477

The Hague, Museum Meermanno-

Westreenianum

MS 10 B 23: 355 n. 61

Hildesheim, Dombibliothek

MS St Godehard 1: 355 n. 61

Jerusalem, National Library of Israel

Yah MS Var 4: 467 n. 96, 478

Yah MS Var 8: 467 n. 96, 477

Yah MS Var 9: 467 n. 96, 478
Yah MS Var 11: 467 n. 96, 477

Yah MS Var 12: 467 n. 96, 482

Yah MS Var 13: 475, 467 n. 96

Yah MS Var 14-15: 476, 467 n. 96

Yah MS Var 16: 467 n. 96, 481

Kew, The National Archives

PROB 11/49/251: 375 n. 15-16, 378 n. 31

PROB 11/116/532: 377 n. 24

Lichfield, Cathedral Library

MS 1: 483-98

Lisbon, Museu Calouste Gulbenkian MS LA 210: 479

London, British Library

Add. 38662: 296-327, 296 n. 1, 299 fig. 1, 306 n. 26

Add. 38663: 296-327, 296 n. 1, 299 fig. 2, 306 n. 26

Add. 38664: 296 n. 1

Add. 40142: 296-327, 296 n. 1, 301 fig. 3, 306 n. 26

Add. 40143: 296 n. 1

Add. MS 43460: 469

Add. MS 48985: 474

Add MS 52660: 452 n. 33-34, 462 n. 70, 466 n. 90-91

Add. MS 52653: 446 n. 6, 447 n. 7, 449 n. 16-17

Add. MS 52656: 458 n. 51

Add. MS 52657: 458 n. 49, 472 n. 99, 476

n. 106

Add. MS 52658: 452 n. 31

Add. MS 52662: 459 n. 55, 461 n. 67, 462

n. 68

Add. MS 52670: 460 n. 58, 462 n. 72 and 75

Add. MS 52692: 462 n. 73

Add. MS 53652: 445 n. 1

Cotton MS Nero A XI: 311

Egerton MS 3055: 472

Egerton MS 3088: 473

Egerton MS 3089: 471 
MS Harley 1862: 335 n. 23

MS. Harley 3698: 390 n. 63

MS Harley 3915: 585

MS Laud Misc. 511: 336 n. 24, 347

MS Royal 15 D 1: 355 n. 61

MS Royal 17: 328 n. 1

MS Royal 17 C.xxxiii (Royal C): $328 \mathrm{n}$.

1, 333, 335-36, 336 fig. 1, 346 n. 37, 365

n. 67

MS Royal 17 D.viii (Royal D): 333, 335-

37, 337 fig. 2, 346 n. 37,348 n. 46, 349

n. 47,352 n. 50,365 n. 67

MS. Sloane 334: 390 n. 63

MS. Sloane 512: 390 n. 63

OR. 13703: 433, 434 fig. 2

Or. 16552: 434

Yates Thompson MS 7: 450 n. 19

London, London Metropolitan Archives, Guildhall Library

MS. 5265/1: 376 n. 17, 377 n. 25, 380 n. 36

MS. $9051 / 5$ : 378 n. 30,385 n. 50

MS. $9171 / 15: 378$ n. 28

London, Quaritch Archives

Commission Book for 1914-1917: 446

n. $2-3$

Commission Book for 1917-1920: 450

n. 19 and 21

Commission Book for 1921-1926: 461

n. $62-63$

London, Victoria and Albert Museum

MS 16: 472

MS Ludwig V 6: 475

MS Ludwig IX 3.: 474

P.159-1910: 585

Los Angeles, The J. Paul Getty Museum MS 48: 478

MS Ludwig XI, 1: 480

Madrid, Biblioteca Nacional

MSS/11267/21: 542
Milan, Biblioteca Nazionale Braidense

AC IX 36: 473

Monza, Biblioteca Capitolare

Monza a-3/10: 514 n. 24

Monza a-3: 513 n. 18, 514, 514 n. 21, 515 n. 27

Monza a-4: 513 n. 18

Monza a-5: 513 n. 18, 515 n. 29

Monza a-6: 513 n. 19, 516 n. 30, 518-19

Monza a-7: 513 n. 19

Monza a-8: 513 n. 18

Monza a-9: 513 n. 19

Monza a-10: 513 n. 19, 514 n. 20, 516

n. 31,517 fig. 2

Monza a-11: 513 n. 19, 516 n. 31

Monza a-12: 513 n. 18

Monza a-13: 513 n. 19, 516 n. 31

Monza a-14: 513 n. 18-19, 516 n. 31

Monza a-15: 513 n. 17

Monza a-16: 513 n. 19, 516 n. 32

Monza a-17: 513 n. 19, 516 n. 31

Monza a-18: 513 n. 19, 516 n. 32

Monza a-19: 513 n. 19

Monza a-20: 513 n. 18

Monza a-21: 513 n. 18

Monza a-22: 513 n. 18, 514 n. 24, 515 n.

27, 516 n. 30,519

Monza a-23: 513 n. 19, 514 n. 24, 515

n. 27

Monza a-24: 513 n. 18

Monza a-25: 513 n. 18, 514 n. 24, 515

n. 27

Monza a-26: 513 n. 19

Monza a-27: 513 n. 16

Monza b-1: 513 n. 16

Monza b-2: 513 n. 19, 516 n. 31

Monza b-3: 513 n. 19, 515, 515 n. 25

Monza b-4: 513 n. 19, 515, 515 n. 28

Monza b-5: 513 n. 19, 514 n. 24, 515

n. 27

Monza b-7: 513 n. 16

Monza b-9: 514 n. 24, 515 n. 27

Monza e-4: 513 n. 18, 516 n. 31 
Manuscript Studies, Vol. 2 [2018], Iss. 2, Art. 1

Monza e-5: 513 n. 18

Monza e-6: 513 n. 17 and 19

Monza e-8: 513 n. 19

Monza e-9: 513 n. 16

Monza e-11: 513 n. 18

Monza e-13: 513 n. 19, 516 n. 31, 519

Monza i-11: 513 n. 17

Münster, Bibliothek Universität Münster

MS NR 1003: 481

New Haven, Yale University, Beinecke Rare

Book and Manuscript Library

MS 111: 480

MS 400: 449, 449 n. 18, 479

MS 402: 471

MS 407: 475

MS 413: 470

MS 414: 472

MS Osborn fa42: 472

New York, Metropolitan Museum of Art 1997.320: 473

New York, Morgan Library and Museum ARC 1310: 458 n. 50, 463 n. 78

MS G 17: 471

MS M 777: 450 n. 21, 471

MS M 808: 473

MS M 826: 469

MS M 855: 473

MS M 860: 470

MS M 862: 470

MS M 883: 471

MS M 939: 472

MS M 962: 471

New York, New York Public Library

MS M 834: 479

MS M 1004: 479

MS M 1110: 479

Spencer MS 27: 451, 480-81

Spencer MS 28: 480

Spencer MS 29: 477

Spencer MS 64: 481

Thai MS.6: 432
Oslo, Schøyen Collection

MS 50: 470-71

Oxford, Bodleian Library

Digby 23: 322, 322-23 n. 87

MS 48: 326 n. 100

MS. Ashmole 1505: 369-91, 371 fig. 1, 272 fig. 2, 373 figs. 3-4, 374 fig. 5

MS Bodley 978: 328-68, 328 n. 1, 341 n. 33, 342 fig. 3, 343 fig. 4, 344 fig. 5, 346 n. 37, 347 n. 43,348 n. 46, 349 fig. 6, 349 n. 47-48, 352 n. 50-51, 353 n. 55, 357 fig. 7, 358 n. 64 , 361 fig. 8,361 n. 67,362 n. 68 , 366 n. 78,368 n. 80

MS Pali a.27 (R): 428 n. 3, 431, 444 MS Phillipps-Robinson C 719: $450 \mathrm{n}$. 22-24, 451 n. 25-26 and 29, 458 n. 47, 459 n. $53-54$

Oxford, Lincoln College

MS Lat. 150: 473

Oxford, Trinity College

MS 93: 332 n. 14,583

Oxford, Worcester College

MS E. 10. 7: 583

Paris, Bibliothèque nationale de France MS Éth. 35: 415 n. 71

MS fr. 24766: 300, 300-301 n. 7, 302 fig. 4, 304-5, 309

MSS n.a.f. 15939-15944: 475

MS n. a. lat. 3115: 478

MS n. a. lat. 3119: 480

Paris, l'École française d'Extrême-Orient EFEO 39: 434, 435 fig. 3

EFEO 40: 432

Phillipps, Sir Thomas, collection of MS 125: 474

MS 134/3948: 475

MS 137: 480

MS 240: 477

MS 250: 480

MS 385: 472 


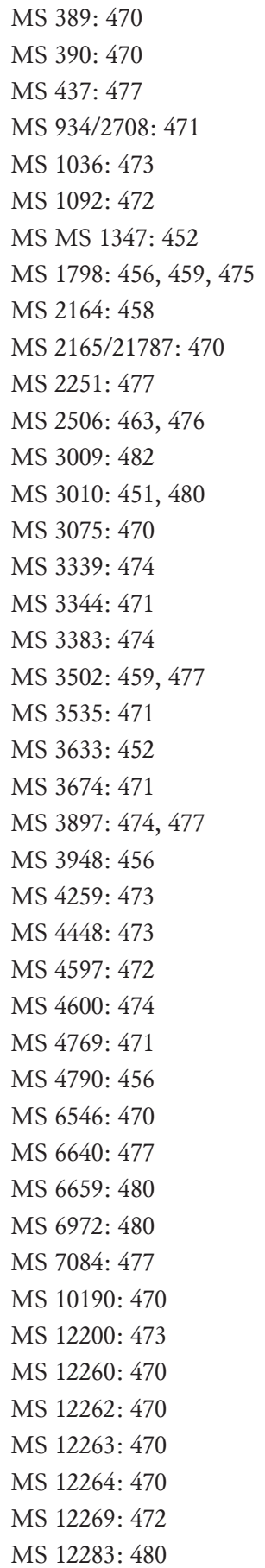

MS 12348: 471

MS 14122: 451, 470

MS 21948: 471

Private Archive of the Escalante family Historia de los reyes moros de Granada: 544-67, 548 fig. 1,550 n. 18 and 22-23, 551 fig. 2, 551 n. 24, 553 fig. 3, 554 fig. 4, 555 fig. 5

Petchaburi, Thailand, Wat Lat Manuscript: 433

Philadelphia, Philadelphia Museum of Art 1945-65-6: 480

Philadelphia, University of Pennsylvania Rare Book and Manuscript Library MS Codex 730: 528, 530 fig. 3, 531, 531 nn. 20-22, $532 \mathrm{nn} .23-26$ and 30-34, $533 \mathrm{nn} .37-39,41,43-47,49$ and 53, 534 nn. 56-60, 62-63 and 65-73, 535 nn. $74-75,80-82$ and 84,536 n. 85,87 and 90-95, $537 \mathrm{nn} .96-99,101-2$ and 104-113, 538 nn. 119-22, 124-25, 12833 and $135-6,539$ nn. 137-40, 145-50 and 152

MS Codex 741: 528, 529 fig. 2, 531, 531 nn. 20-22, $532 \mathrm{nn} .23-30,32$ and 35, 533 nn. 36, 40, 42, 46-48 and 50-52, $534 \mathrm{nn}$. 54-58, 60-67 and 71, $535 \mathrm{nn} .74-83,536$ nn. 85-90, 93 and 95, $537 \mathrm{nn} .97$ and 99-115, 538 nn. 116-20, 123, 125-27, 129-31 and 133-34, 539 nn. 141-43, 145-46 and 151 Ms. Coll. 591: 509 n. 4, 510 fig. 1

Princeton, Princeton University Library

Kane MS 31: 476

Kane MS 33: 482

Kane MS 43: 480

Kane MS 48: 482

MS Garrett 143: 296 n. 1

Rome, Biblioteca Casanatense

MS 969: 269 


\section{4 | Journal for Manuscript Studies}

MS 1730: 267-95, 267 n. 1, 267-68 n. 3, 268 n. 4, 269 n. 6, 270 fig. 1, 272 figs. 2-3, 273 fig. 4, 277 fig. 5, 277 nn. 17-21, 278 figs. $6-7,279$ n. 22 , 280 figs. 8-9, 280 n. 23, 281 figs. $10-11,281$ n. 24 , $282 \mathrm{nn} .25-27,283$ figs. 12-14, 284

n. 28,285 figs. $15-16,285$ n. 29,286

n. 30, 287 figs. 17-18, 288 fig. 19, 288

n. 31, 289 fig. 20, 290 figs. 21-22, 291

fig. 23, 291 n. 32, 292 fig. 24,293

fig. 25

MS 2206: 421 n. 75

Rome, Biblioteca Nazionale Centrale

VE 1006: 470

VE 1190: 469

VE 1347: 470

VE 1348: 470

VE 1357: 470

VE Sessor 590: 470

San Lorenzo de El Escorial, Real Biblioteca del Monasterio de El Escorial

Y/III/6: 542, 558 n. 31

San Marino, Huntington Library

HM 31151: 471

Siena, Biblioteca Comunale degli Intronati MS D V 13: 405 n. 37, 418, 420 fig. 2

Stockholm, Nationalmuseum

NMB 1960: 479

Stuttgart, Landesbibliothek

Theol. \& Phil. Fol. 341: 472
Tokyo, Senshu University

MS 7: 467, 467 n. 95, 482

Vatican City, Biblioteca Apostolica Vaticana Stamp. Barb. A VIII 18,: 403, 408 n. 51, 420

Vat. et. 1: 400, 400 n. 25, 409-10, $410 \mathrm{n}$. 59, 421 n. 75, 422, 424 fig. 5, 425, 425 n. 81,426

Vat. et. 2: 400, 400 n. 25, 401, 409, 425-26

Vat. et. 5: 407

Vat. et. 10: 425 n. 82

Vat. et. 15: 406, 406 n. 39, 425

Vat. et. 16-18: 425 n. 82

Vat. et. 25 : 406-7 n. 44,407

Vat. et. 35: 400, 406, 406 nn. 39-40, 409, 409 n. 53, 421, 422 fig. 3, 425 n. 82, 426

Vat. et. 40: 426

Vat. et. 42, 49, 52, and 57: 425 n. 82

Vat. et. 66: 400, 402-6, 406 n. 39, 407 n. 45, 408 n. 51, 409, 411, 418, 419 fig. 1, 423 n. 80,425 n. 82,426

Vat. lat. Ms. 2648: 269

Vat. lat. Ms. 3978: 269

Vat. lat. Ms. 5092: 269

Vat. lat. Ms. 6177: 398 n. 15, 401 n. 29

Vat. lat. Ms. 6178: 398 n. 16

Vaticano Rossiano 865 MS Vat. Ross 865:

400, 400 n. 25, 409, 422, 423 fig. 4, 426

Vatican City, Archivio Segreto Vaticano

AA., Arm. I-XVIII, no. 2953: $395 \mathrm{nn}$.

7-8, 396 nn. 9-10, 397 nn. 13-14, 398

nn. $17-18,404$ n. 34,416 n. 72 